

\section{MEDIA PEMBELAJARAN BERBASIS INTERNET}

Penulis:

Awal Kurnia Putra Nasution, M.TPd

Penyunting Kepala:

Mustafa Kamal, M.Ed

Penyunting Ahli:

Muhammad Riza, MA

Muhammad Hasyimsyah Batubara, M.Hum

Penyunting Bahasa:

Imam Munandar, M.TESOL

Desain Sampul dan Tata Letak:

Awal Kurnia Putra Nasution, M.TPd

Penerbit:

\section{As-Salam Press}

Alamat : Jl. Ganensa Baru Kelurahan Kemili Kecamatan Bebesan, Takengon Aceh Tengah, Aceh

Telp. (+62) 8126965878; E-mail : asosiasiassalam@gmail.com

Redaksi:

\section{As-Salam Press}

Alamat : Jl. Ganensa Baru Kelurahan Kemili Kecamatan Bebesan, Takengon Aceh Tengah, Aceh

Telp. (+62) 8126965878; E-mail : asosiasiassalam@gmail.com

\section{Cetakan pertama 2019}

ISBN: 978-602-50546-1-7

Hak cipta dilindungi oleh undang-undang.

Dilarang memperbanyak atau memindahkan sebagian atau seluruh isi buku ini dalam bentuk apapun, baik secara elektronis maupun mekanis, termasuk memfotocopy, merekam atau dengan sistem penyimpanan lainnnya, tanpa izin tertulis dari penulis.

ISBN 978-602-50546-1-?

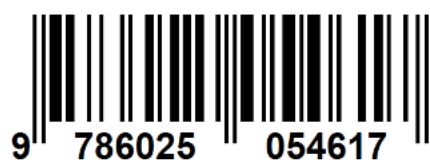




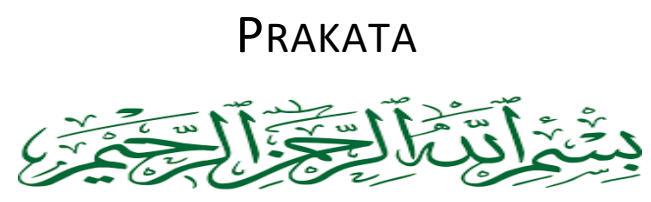

Alhamdulillahirabbil'alamin, puji beserta syukur penulis panjatkan kehadirat Allah SWT, berkat rahmat dan karunia-Nya penulis dapat menyelesaikan buku berjudul Media Pembelajaran Berbasis Internet ini.

Secara garis besar buku ini merupakan hasil tulisan yang berasal dari pengalaman penulis dalam menggunakan media pembelajaran sewaktu mengajar dikelas. Buku ini juga disusun merupakan bagian dari usaha penulis untuk memberikan kontribusi terhadap dunia pendidikan yang telah menjadi pekerjaan penulis sehari-hari. Buku ini terdiri dari 5 bab yang berisikan alternative pilihan media pembelajaran bagi tenaga pengajar yang dapat digunakan di dalam kelas maupun di luar kelas.

Selesainya buku ini tentunya merupakan anugrah Allah SWT, dukungan dan doa dari keluarga penulis, Ibunda Carona Elianur, M.Pd., istri tercinta Nur Zahara, S.Si., dan anak-anak penulis Nadhifa Almaira Azzahwa Nasution, Aldric Muhammad Rizqi Nasution yang selalu membawa kecerian sehingga memudahkan penulis menyelesaikan buku ini. Terima kasih tak terhingga juga penulis ucapkan kepada rekan-rekan Mustafa Kamal, MEd, Muhammad Riza, MA, yang selalu memberikan bantuan kapanpun penulis butuhkan.

Akhirnya penulis berharap buku ini dapat bermanfaat bagi penulis dan bagi pembaca dan dapat memberikan kontribusi yang besar kedepannya.

Takengon, Novemver 2019 


\section{DAFTAR ISI}

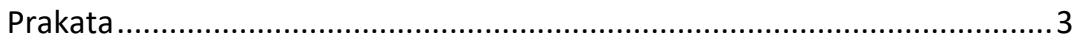

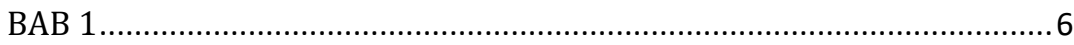

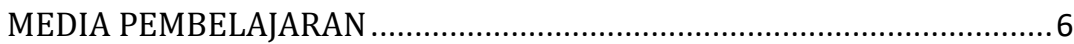

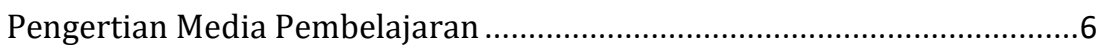

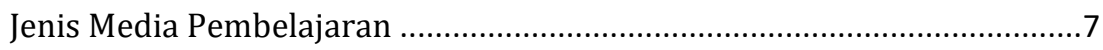

Fungsi dan Manfaat Media Pembelajaran ..............................................

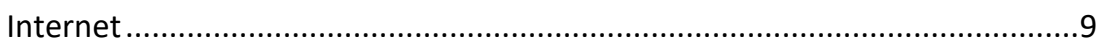

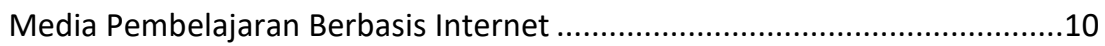

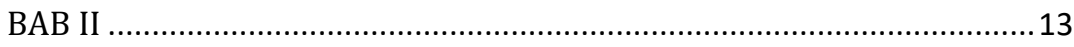

BLOG SEBAGAI MEDIA PEMBELAJARAN ..........................................13

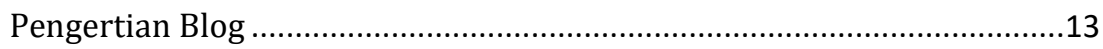

Sejarah Perkembangan Blog............................................................14

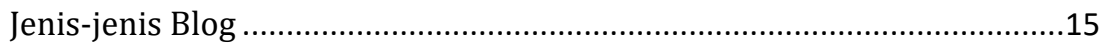

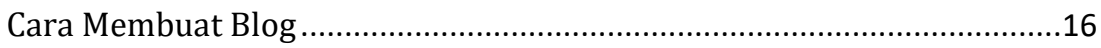

Pemanfaatan Blog sebagai media pembelajaran .....................................27

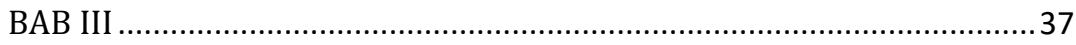

FACEBOOK SEBAGAI MEDIA PEMBELAJARAN .......................................

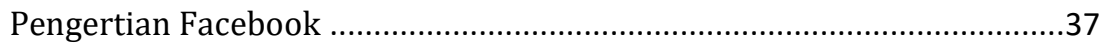

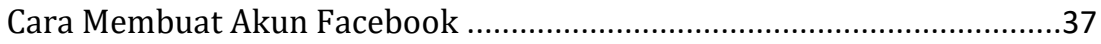

Pemanfaatan Facebook sebagai media pembelajaran...............................40

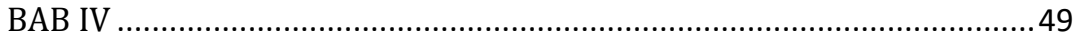

WHATSAPP SEBAGAI MEDIA PEMBELAJARAN ......................................49

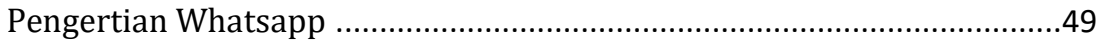

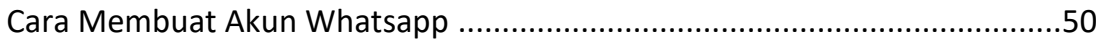

Pemanfaatan whatsapp sebagai media pembelajaran ...............................55

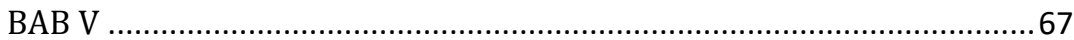

WEBSITE SEBAGAI MEDIA PEMBELAJARAN .........................................67 


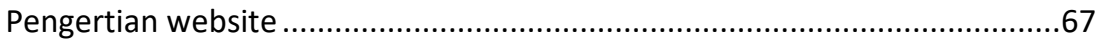

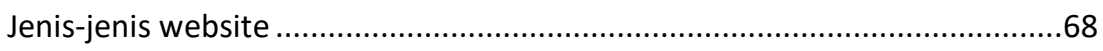

Pemanfaatan website sebagai media pembelajaran .....................................70

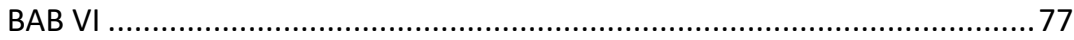

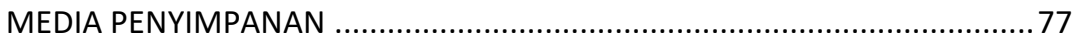

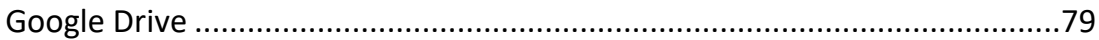

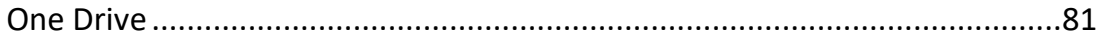

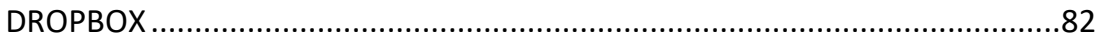

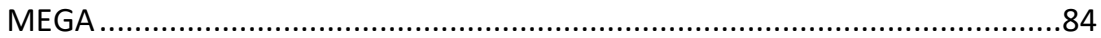

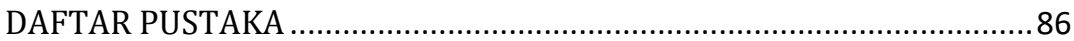




\section{BAB 1}

\section{MEDIA PEMBELAJARAN}

\section{Pengertian Media Pembelajaran}

Media Pembelajaran merupakan hal yang tidak bisa dipisahkan dengan proses belajar mengajar. Proses belajar mengajar akan sangat terbantu dengan adanya media pembelajaran yang tepat. Pemilihan media pembelajaran yang tepat menjadi salah satu tolak ukur berhasilnya pemanfaatan media pembelajaran dalam proses belajar mengajar. Pemanfaatan media pembelajaran sekarang ini sudah mulai merambah dunia maya, dalam hal ini dengan memanfaatkan internet sebagai media pembelajaran.

Kata media berasal dari kata latin, merupakan bentuk jamak dari kata medium. Secara harfiah kata tersebut mempunyai arti perantara atau pengantar, yaitu perantara sumber pesan (a source) dengan penerima pesan (a receiver). Jadi, dalam pengertian yang lain, media adalah alat atau sarana yang dipergunakan untuk menyampaikan pesan dari komunikator kepada khalayak. ${ }^{1}$ Dalam bahasa Arab, media adalah perantara atau pengantar pesan dari pengirim kepada penerima pesan. ${ }^{2}$ Menurut AECT (Association of Education and Communication Technology) yang dikutip oleh Basyaruddin (2002), media adalah segala bentuk yang dipergunakan untuk proses penyaluran informasi. ${ }^{3}$ Sedangkan pengertian lain media adalah alat bantu apa saja yang dapat dijadikan sebagai penyalur pesan guna mencapai tujuan pembelajaran. ${ }^{4}$

Media pembelajaran menurut Gagne (1992) adalah berbagai jenis komponen dalam lingkungan siswa yang dapat merangsangnya

1 http://www.pengertianahli.com/2014/07/pengertian-media-dan-jenismedia.html

${ }^{2}$ Azhar Arsyad, Media Pembelajaran, (Jakarta: PT. Raja Grafindo Persada, 2005).

${ }^{3}$ Asnawir dan M. Basyiruddin Usman, Media Pembelajaran, (Jakarta: Ciputat Pers, 2002).

${ }^{4}$ Djamarah, Syaiful Bahri dan Aswan Zain, Strategi belajar Mengajar, (Jakarta : PT. Rineka Cipta, 2006). 
untuk belajar. Sejalan dengan pendapat Briggs yang mendefinisikan media pembelajaran sebagai bentuk fisik yang dapat menyajikan pesan yang dapat merangsang siswa untuk belajar. 5 Kedua ahli ini menyimpulkan bahwa pengertian media mengacu pada penggunaan alat berupa benda untuk membantu proses penyampaian pesan.

Dari beberapa defenisi yang diuraikan sebelumnya, maka dapat diambil sebuah kesamaan bahwa media pembelajaran merupakan sarana yang dapat digunakan atau dimanfaatkan untuk mempermudah dan mendukung proses pembelajaran terjadi. Proses pembelajaran pada hakikatnya adalah proses menyampaikan informasi kepada siswa dengan menanfaatkan alat berupa benda. Media pembelajaran yang digunakan akan semakin efektif apabila dapat merangsang siswa untuk belajar, sehingga tercapai tujuan pelajaran yang telah ditetapkan diawal proses pembelajaran.

\section{Jenis Media Pembelajaran}

Secara garis besar, jenis-jenis media secara umum dapat dibagi menjadi:

1) Media Visual: media visual adalah media yang bisa dilihat, dibaca dan diraba. Media ini mengandalkan indra penglihatan dan peraba. Berbagai jenis media ini sangat mudah untuk didapatkan. Contoh media yang sangat banyak dan mudah untuk didapatkan maupun dibuat sendiri. Contoh: media foto, gambar, komik, gambar tempel, poster, majalah, buku, miniatur, alat peraga dan sebagainya.

2) Media Audio: media audio adalah media yang bisa didengar saja, menggunakan indra telinga sebagai salurannya. Contohnya: suara, musik dan lagu, alat musik, siaran radio dan kaset suara atau CD dan sebagainya.

3) Media Audio Visual: media audio visual adalah media yang bisa didengar dan dilihat secara bersamaan. Media ini menggerakkan indra pendengaran dan penglihatan secara bersamaan. Contohnya: media drama, pementasan, film, televisi dan media yang sekarang menjamur, yaitu VCD. Internet termasuk dalam bentuk media audio visual, tetapi lebih lengkap dan menyatukan semua jenis format media, disebut Multimedia karena berbagai format ada dalam internet.

\footnotetext{
${ }^{5}$ Gagne, Robert M, Briggs Leslie J, and Wager Walter W., Principles of Instructional Design, (USA : Holt, Rinehart and Winston, 1992)
} 
FungSi dan ManfaAt Media Pembelajaran

Levie \& Lents mengemukakan empat fungsi media pembelajaran, khususnya media visual, yaitu:

1) Fungsi Atensi

Fungsi atensi media visual merupakan inti, yaitu menarik dan mengarahkan perhatian siswa untuk berkonsentrasi kepada isi pelajaran yang berkaitan dengan makna visual yang ditampilkan atau menyertai teks materi pelajaran. Seringkali pada awal pelajaran siswa tidak tertarik dengan materi pelajaran atau mata pelajaran itu merupakan salah satu pelajaran yang tidak disenangi oleh mereka sehingga mereka tidak memperhatikan. Media gambar khususnya gambar yang diproyeksikan melalui overhead projector dapat menenangkan dan mengarahkan perhatian mereka kepada pelajaran yang akan mereka terima. Dengan demikian, kemungkinan untuk memperoleh dan mengingat isi pelajaran semakin besar.

2) Fungsi Afektif

Media visual dapat terlihat dari tingkat kenikmatan siswa ketika belajar (atau membaca) teks yang bergambar. Gambar atau lambang visual dapat menggugah emosi dan sikap siswa, misalnya informasi yang menyangkut masalah social atau ras.

3) Fungsi Kognitif

Fungsi kognitif media visual terlihat dari temuan-temuan penelitian yang mengungkapkan bahwa lambang visual atau gambar memperlancar pencapaiaan tujuan untuk memahami dan mengingat informasi atau pesan yang terkandung dalam gambar.

4) Fungsi Kompensatoris

Fungsi kompensatoris media pembelajaran terlihat dari hasil penelitian bahwa media visual yang memberikan konteks untuk memahami teks membantu siswa yang lemah dalam membaca untuk mengorganisasikan informasi dalam teks dan mengingatnya kembali. Dengan kata lain, media pembelajaran berfungsi untuk mengakomodasikan siswa yang lemah dan lambat menerima dan memahami isi pelajaran yang disajikan dengan teks atau disajikan secara verbal. ${ }^{6}$

\footnotetext{
${ }^{6}$ Levie, W. H. and Lentz, R., Effects of text illustrations: a review of research, Educational Communication and Technology, (Journal, 1982)
} 
Media pembelajaran, menurut Kemp \& Dayton (1985:28), dapat memenuhi tiga fungsi utama apabila media itu digunakan untuk perorangan, kelompok, atau kelompok pendengar yang besar jumlahnya, yaitu :

1) Memotivasi minat atau tindakan, Untuk memenuhi fungsi motivasi, media pembelajaran dapat direalisasikan dengan teknik drama atau hiburan. Hasil yang diharapkan adalah melahirkan minat dan merangsang para siswa atau pendengar untuk bertindak (turut memikul tanggung jawab, melayani secara sukarela, atau memberikan subangan material). Pencapaian tujuan ini akan memperngaruhi sikap, nilai, dan emosi.

2) Menyajikan informasi, Untuk tujuan informasi, media pembelajaran dapat digunakan dalam rangka penyajian informasi dihadapan sekelompok siswa. Isi dan bentuk penyajian bersifat amat umum, berfungsi sebagai pengantar, ringkasan laporan, atau pengetahuan latar belakang. Penyajian dapat pula berbentuk hiburan, drama, atau teknik motivasi. Ketika mendengar atau menonton bahan informasi, para siswa bersifat pasif. Partisipasi yang diharapkan dari siswa hanya terbatas pada persetujuan atau ketidaksetujuan mereka secara mental, atau terbatas pada perasaan tidak/kurang senang, netral, atau senang.

3) Memberi instruksi.

Media berfungsi untuk tujuan instruksi di mana informasi yang terdapat dalam media itu harus melibatkan siswa baik dalam benak atau mental maupun dalam bentuk aktivitas yang nyata sehingga pembelajaran dapat terjadi. Materi harus dirancang secara lebih sistematis dan psikologis dilihat dari segi prinsipprinsip belajar agar dapat menyiapkan instruksi yang efektif. Di samping menyenangkan, media pembelajaran harus dapat memberikan pengalaman yang menyenangkan dan memenuhi kebutuhan perorang siswa.

\section{INTERNET}

Pada saat ini, internet telah menjadi salah satu kebutuhan dalam kehidupan sehari-hari, khususnya dunia pendidikan. Banyak hal yang dapat dilakukan dengan berbantuan internet, seperti mencari materi pelajaran, berkomunikasi, sarana pembelajaran atau media 
pembelajaran, sarana mencari informasi beasiswa, sarana mencari ajang lomba pendidikan, dan sarana pendidikan jarak-jauh. Materi pelajaran yang didapat dari internet dapat berupa bahan pelajaran, jawaban dari tugas-tugas, tutorial dalam pratikum, sampai informasi pendukung materi pelajaran. Berkomunikasi yang dilakukan dengan bantuan atau media internet dapat berupa komunikasi antara siswa dengan siswa maupun antara siswa dan guru, sehingga proses pembelajaran dapat dilakukan dengan lebih efektif dan efisien.

Internet (kependekan dari interconnection-networking) adalah seluruh jaringan komputer yang saling terhubung menggunakan standar sistem global Transmission Control Protocol/Internet Protocol Suite (TCP/IP) sebagai protokol pertukaran paket (packet switching communication protocol) untuk melayani miliaran pengguna di seluruh dunia.Rangkaian internet yang terbesar dinamakan Internet. Cara menghubungkan rangkaian dengan kaidah ini dinamakan internetworking ("antarjaringan"). ${ }^{7}$

\section{Media Pembelajaran Berbasis Internet}

Media pembelajaran merupakan alat bantu untuk menjabarkan pesan dan informasi yang berasal dari guru utnuk siswa dengan tujuan untuk memudahkan proses pembelajaran. Pemanfaatan media pembelajaran saat kegiatan belajar, diharapkan pikiran, perasaan, perhatian dan minat siswa dapat terangsang sehingga siswa dapat menerima dan memahami materi pelajaran dan informasi dari guru dengan baik. Media pembelajaran berbasis internet ini merupakan media pembelajaran yang dapat prakteknya memanfaatkan internet sebagai media penyampai materi pelajaran dan berbagai informasi yang dibutuhkan dari guru ke siswa. Media pembelajaran berbasis internet ini diharapkan dapat menjadi alternative media pembelajaran yang digunakan oleh guru untuk mencapai hasil belajar yang lebih maksimal.

Media pembelajaran berbasis internet terus berkembang mengikuti perkembangan teknologi dan komunikasi, berikut ini beberapa contoh media pembelajaran yang dalam penggunaannya dengan memanfaatkan internet.
a) $B \log$
b) Facebook
c) Whatsapp

${ }^{7}$ https://id.wikipedia.org/wiki/Internet 
d) Website

e) Edmodo

f) Moodle

Media pembelajaran berbasis internet ini juga memiliki Kelebihan Dan Kekurangan, hal merupakan dua sisi yang tidak dapat dipisahkan. Dengan mengetahui kelebihan dan kekurangan media pembelajaran berbasis internet ini diharapkan guru sebagai pemanfaat media pembelajaran dapat menggali kelebihan dan meminimalisasi kekurangan dari media ini. Berikut ini beberapa kelebihan media pembelajaran berbasis Internet:

a) Internet sebagai media pembelajaran memberikan sambungan (konektivitas) dan jangkauan yang sangat luas sehingga akses data dan informasi tidak dibatasi waktu, tempat, dan negara.

b) Proses belajar atau akses informasi dapat dilakukan tanpa terbatas ruang dan waktu. Bahkan proses belajar dapat dilakukan 24 jam tanpa ditentukan jam belajar seperti belajar disekolah pada umumnya.

c) Belajar dapat dilakukan tanpa harus bertatap muka antara guru dan siswa, tapi cukup dengan memanfaatkan media pembelajaran berbasis internet ini, guru dan siswa dapat berkomunikasi dengan baik.

d) Proses belajar dengan memanfaatkan internet lebih cepat bila dibandingkan dengan mencari informasi pada halaman-halaman buku-buku di perpustakaan. Hanya perlu menulis kata pencarian pada halaman pencari seperti google.com, maka apa yang dicari akan muncul pada layar komputer.

e) Media pembelajaran berbasis internet ini juga dapat dikatakan lebih murah dibandingkan harus membeli beberapa buku dengan judul yang berbeda-beda.

f) Memanfaatkan media pembelajaran berbasis internet membuat ilmu yang akan dipelajari tidak terbatas, karena banyak sekali informasi tambahan yang didapat hanya dengan mencari pada mesin pencari seperti google.com.

Selain memiliki banya kelebihan media pembelajaran berbasis internet ini juga memeliki beberapa kekurangan, kekurangan Media pembelajaran berbasis Internet:

1) Proses sosialisasi dapat terganggu, seringnya menggunakan media pembelajaran berbasis internet juga dapat mengganggu 
proses sosialisasi siswa, karena waktu sosialisasi siswa dengan guru dan siswa dengan siswa menjadi terbatas.

2) Penggunaan akses internet yang tidak baik, menggunakan media pembelajaran berbasis internet dapat memeberi dampak negative dengan memberi siswa wawasan yang tidak seharusnya didapatkan, seperti akses pada situs-situs kekerasan, judi, dan pornografi.

3) Akses internet yang terbatas dan terganggu, akses internet menggunakan pulsa atau uang untuk membelinya, hal ini menjadi masalah tersendiri disaat siswa tidak memiliki paket internet sehingga proses pembelajaran tidak dapat dilaksanakan. 


\section{BAB II}

\section{BLOG SEBAGAI MEDIA PEMBELAJARAN}

\section{PENGERTIAN BLOG}

Blog atau sering juga di sebut weblog adalah media berbasis internet yang dapat digunakan digunakan secara personal, baik individual maupun institusional. Tidak ada persyaratan personal yang diberikan dari pihak manapun untuk bisa memiliki dan mengelola blog sendiri. Penggunaan aplikasi tergolong mudah dan pengelolaannya yang tidak rumit membuat media ini bisa dioperasikan oleh semua kalangan masyarakat khususnya pendidik. Selain karena sifatnya yang ada dalam jaringan internet, beberapa kelebihan dari blog lainya adalah sifatnya berdiri sendiri sebagai media. Blog memungkinkan terjadinya aktifitas antara sumber dengan penerima informasi. Informasi yang disampaikan dapat langsung direspon, ditambahi, dikoreksi dan diperkaya oleh orang lain. Oleh karena itu, suatu topik mungkin bisa menjadi lebih menarik dengan adanya diskusi antara blogger dengan pengunjung weblognya. Kemampuan teknis atau kemampuan dasar jurnalisme tidak diperlukan untuk mempublikasikan informasi dalam weblog.

Blog adalah singkatan dari weblog. Blog adalah jenis situs web yang dikembangkan dan dikelola oleh individu dengan mengunakan perangkat lunak (software) online atau Platform host yang sangat mudah pengguna, dengan ruang untuk menulis. Blog menampilkan publikasi online instan dan mengajak publik untuk membaca dan memberikan umpan balik sebagai komentar. ${ }^{8}$ Blog sering diartikan akronim weblog, seperti definisi dari wikipedia, Blog didefinisikan sebagai bentuk aplikasi web yang menyerupai tulisan-tulisan (yang dimuat sebagai posting) pada sebuah halaman umum. Situs ini biasanya

${ }^{8}$ Gween Solomon, lynne Scrum, Web 2.0 Panduan bagi para pendidik (Jakarta : PT indekx, 2011) 
dapat diakses oleh semua pengguna internet sesuai dengan topik dan tujuan pengguna blog tersebut. ${ }^{9}$

\section{Sejarah Perkembangan Blog}

Blog adalah kependekan dari Weblog, istilah ini pertama kali digunakan oleh Jorn Barger pada bulan Desember tahun 1997. Jorn Barger menggunakan istilah Weblog untuk menyebut kelompok website pribadi yang selalu diupdate secara continue dan berisi linklink ke website lain yang mereka anggap menarik disertai dengan komentar-komentar mereka sendiri. Secara garis besar, Weblog dapat dirangkum sebagai kumpulan website pribadi yang memungkinkan para pembuatnya menampilkan berbagai jenis isi pada web dengan mudah, seperti karya tulis, kumpulan link internet, dokumen-dokumen, gambar ataupun multimedia. ${ }^{10}$

Para pembuat blog ini sering di sebut dengan nama Blogger. Melalui Blognya kepribadian Blogger menjadi begitu mudah dikenali berdasarkan topik apa yang disukai, apa tanggapan terhadap link-link yang di pilih dan isu-isu didalamnya oleh karena itu Blog bersifat sangat personal. Perkembangan lain dari Blog yaitu ketika Blogger memuat tulisan tentang apa yang sedang di pikirkan, rasakan, hingga apa yang dia lakukan sehari-hari. Blog personal dapat di sebut juga Diary Online yang berada di Internet. Satu-satunya hal yang membedakan Blog Diary atau Jurnal yang biasa kita miliki adalah bahwa blog dibuat untuk dibaca orang lain. Seiring perkembangan weblog dari waktu ke waktu, pengertian weblog juga akan berkembang seiring dengan ide - ide dan kemauan para Blogger.

Blog pertama kemungkinan besar adalah halaman "What's New" pada browser Mosaic yang dibuat oleh Marc Andersen pada tahun 1993. Mosaic adalah browser pertama sebelum adanya Internet Explorer bahkan sebelum Nestcape..Kemudian pada Januari 1994 Justin Hall memulai website pribadinya "Justin's Home Page" yang kemudian berubah menjadi "Links from the Underground" yang mungkin dapat disebut sebagai Blog pertama seperti yang kita kenal sekarang.

Pada tahun 1998, jumlah Blog yang ada masih sangat sedikit. Hal ini disebabkan karena saat itu diperlukan keahlian dan

\footnotetext{
${ }^{9}$ Agung Herutomo, Conquering Web 2.0, (Jakarta: PT Elex media Komputindo, 2010).

10 http://www.muhanik.com/2017/09/Sejarah-perkembangan-bloglengkap.html
} 
pengetahuan khusus tentang website, HTML, dan web hosting untuk membuat Blog, sehingga hanya mereka yang berkecimpung di bidang Internet, System Administrator atau Web Designer saja yang kemudian menciptakan Blog-Blog mereka sendiri. Hingga kemudian media blog pertama kali di populerkan oleh Blogger.com yang di miliki oleh PyraLab sebelum akhirnya PyraLab diakuisi (di beli) oleh google.com pada akhir 2002 yang lalu, Semenjak saat itu banyak terdapat aplikasiaplikasi yang bersifat sumber terbuka yang diperuntukkan kepada perkembangan para penulis blog tersebut. Sampai akhirnya saat ini, tidak perlu menjadi seorang programmer untuk menjadi seorang Blogger, karena anda dapat menampilkan seluruh isi dalam web dengan mudah melalui menu editor yang telah banyak disediakan.

\section{JENIS-JENIS BLOG}

Sejak ditemukannya blog sampai sekarang, jenis blog terus berkembang, yang semula hanya bersifat pribadi kini menjadi lebih beragam. Dengan banyaknya jenis blog yang saat ditemukan, melai dari blog yang bersifat pribadi samapai blog yang bersifat public, maka berikut ini adalah jenis-jenis blog yang dapat dikasifikasikan dari sekian banyak blog yang berada di internet:

$>$ Blog politik merupakan blog yang berisi informasi tentang politik, baik profil, kampanye politik, maupun propaganda.

$>$ Blog Pribadi merupakan blog milik perorangan yang biasanya memuat artikel sesuai dengan minat dan hobi si pemilik blog.

$>$ Blog bertopik merupakan blog yang dikususkan membahas tentang topik tertentu, misalnya membahas tentang potografi, bisnis online, pemrograman, dan lain-lain.

$>$ Blog kesehatan adalah blog yang membahas tentang informasi kesehatan.

$>$ Blog sastra adalah blog yang berisi artikel-artikel berbau sastra dan seni, baik yang bersifat lokal, regional, nasional, maupun internasional.

$>$ Blog perjalanan atau Traveling: blog yang membahas tentang informasi

$>$ pariwisata bagi para pehobi traveling.

$>$ Blog riset atau penelitian adalah blog yang berisi jurnal penelitian dan riset milik perorangan maupun institusi riset, baik swasta maupun pemerintah.

$>$ Blog Hukum merupakan blog yang menyediakan informasi tentang hokum dan konsultasi hokum. 
$>$ Blog media: blog tentang informasi terkini sebuah media pemberitaan baik cetak maupun elektronik, misalnya: http://blog.liputan6.com

$>$ Blog agama: blog yang berisi tentang artikel-artikel keagamaan.

$>$ Blog pendidikan: blog yang berisi tentang opini tentang kependidikan, atau blog milik institusi pendidikan.

$>$ Blog Petunjuk (direktory).

$>$ Blog bisnis: blog yang memuat informasi dan referensi tentang bisnis online maupun online, informasi tentang peluang usaha dan hal berbau bisnis

$>$ Blog penganggu (spam.) $)^{11}$

Cara Membuat Blog

Untuk membuat blog di Blogspot gratis, pertama bukalah website https://www.blogger.com/ dan pilihlah menu "CREATE YOUR BLOG".

\section{Publish your passions, your way}

Create a unique and beautiful blog. It's easy and free.

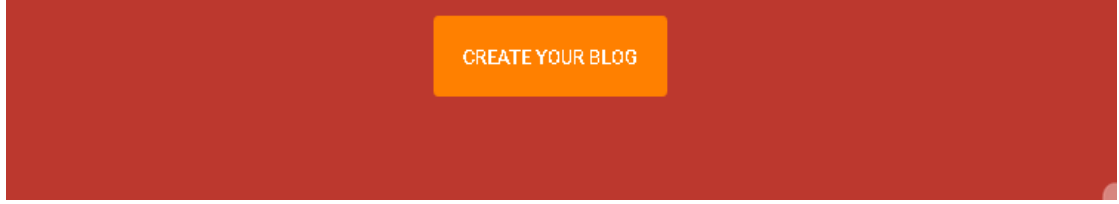

Selanjutnya akan muncul halaman login seperti gambar berikut ini, isilah dengan akun gmail, pilih menu "BERIKUTNYA" dan masukkan password.

${ }^{11}$ Oya suryana, Mataya Studio, Membanggun Blog Wordpress, (Jakarta: PT elex Media Komputindo, 2008) hal. 2-5 


\section{Google \\ Masuk \\ Lanjutkan ke Blogger}

Email atau ponsel

Lupa email?

Proses selanjutnya akan muncul halaman baru untuk memulai membuat blog dengan menambahkan judul/nama blog, memilih nama domain, dan memilih tema untuk blog yang akan dibuat. Apabila tahap diatas sudah selesai selanjutnya pilih menu "Buat blog!" Judul adalah tempat kita untuk memberi judul atau nama blog. Alamat adalah tempat kita untuk memberi alamat blog kita. Tema adalah tempat kita untuk memilih template blog kita, kita bisa merubah-nya nanti pada halaman template, jadi untuk sementara pilih saja yang standar. 


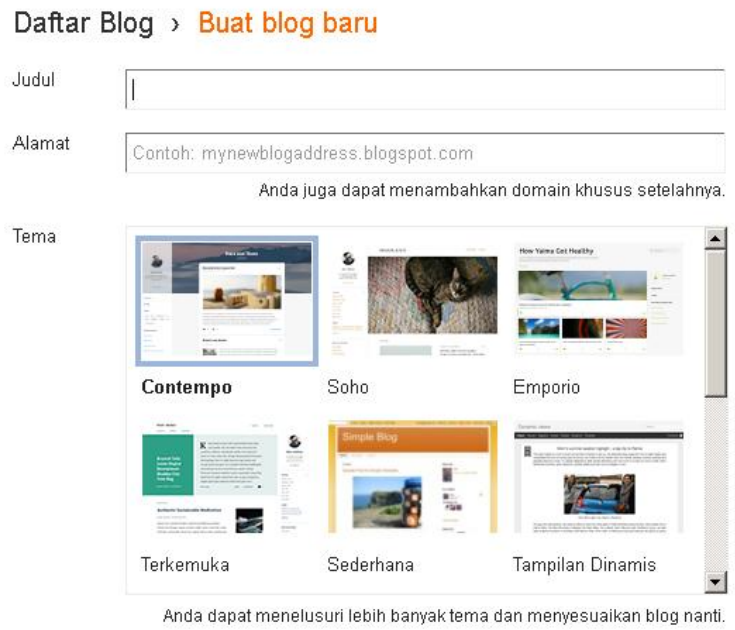

Blog sudah selesai dibuat tetapi belum selesai sepenuhnya. Ada beberapa pengaturan yang perlu dilakukan pada blog yang baru dibuat, agar membuat blog di Blogspot semakin baik, seperti merubah template dan menambah halaman. Tampilan berikut ini adalah dashboard Blogspot yang menyajikan bermacam-macam menu.

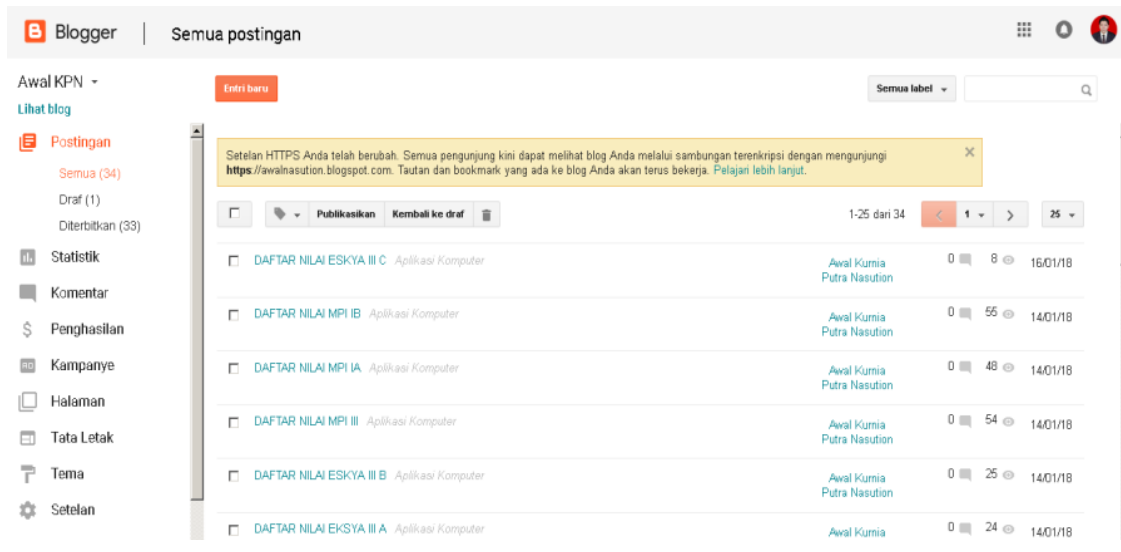


- Menu "Entri baru" merupakan tombol yang bisa digunakan jika ingin membuat post baru.

- Menu "Lihat blog" merupakan tombol yang bisa digunakan jika ingin melihat blog secara live.

- Menu "Postingan" merupakan tombol yang digunakan untuk melihat postingan yang telah dibuat, baik itu postingan yang telah diterbitkan maupun postingan yang masih berupa draft.

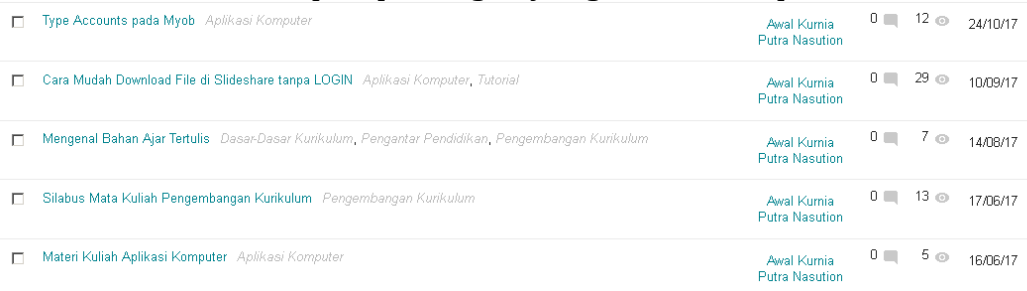

Pada menu ini juga dapat digunakan untuk mempublikasikan artikel yang masih dalam bentuk draft dan untuk menghapus artikel yang telah dipulikasikan.

$\ulcorner$ Publikasikan Kembali ke draf

$\Gamma \quad$ (Entri tanpa judul)

- Menu "Statistik" merupakan tombol yang digunakan untuk melihat statistik blog yang telah dibuat, seperti gambar berikut ini :

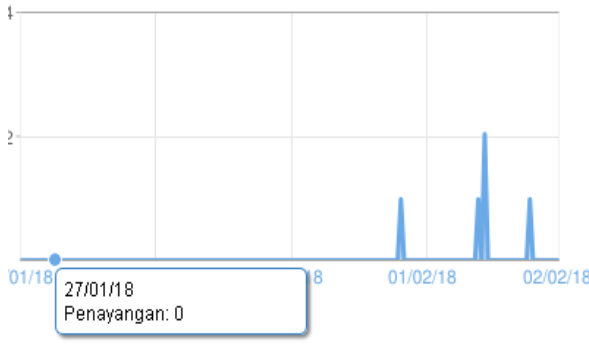

Yang lain»
Postingan

\begin{tabular}{lr} 
Penayangan hari ini & 1 \\
\hline Penayangan kemarin & 3 \\
\hline Penayangan bulan lalu & 430 \\
\hline Histori penayangan sepanjang waktu & 2.030 \\
\hline Pengikut & 0
\end{tabular}

Mengelola pelacakan tayangan halaman Anda sendiri

\section{Sumber Lalu Lintas}

- Menu Komentar digunakan untuk melihat komentar dari pengunjung yang masuk di blog, ada 3 menu pilihan yang diberikan. Pilihan hapus dapat digunakan untuk menghapus komentar dari tampilan komentar di blog, pilhan hapus 
digunakan untuk menghapuskan komentar selamanya, dan spam digunakan untuk memasukkan komentar dalam kategori spam atau pengganggu.

\begin{tabular}{|l|l|l|}
\hline$\square \quad$ Hapus konten & Hapus & Spam \\
\hline
\end{tabular}

- Menu halaman digunakan untuk membuat, mengedit, mempublikasikan maupun menghapus serta melihat Laman atau Halaman yang akan maupun sudah dibuat.

Halaman baru

Publikasikan

Kembali ke draf

- Menu tata letak digunakan untuk melihat atau mengedit tampilan blog, untuk dapat mengedit tampilan blog dengan menekan tombol edit yang disediakan pada tampilan, apakah akan mengedit, icon, header, page, main menu, dan side bar.
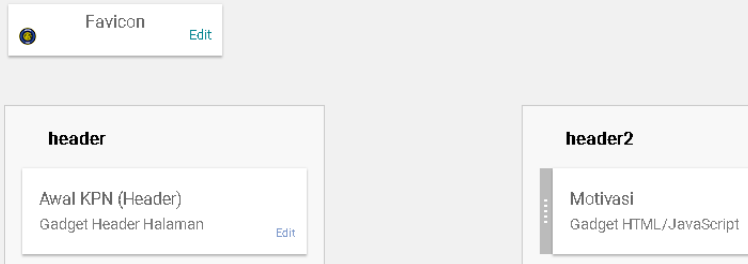

- Menu Tema digunakan untuk mengganti tema dari blog dan mengedit tema dengan menafaatkan edit HTML. Ada dua tampilan yang tampak, pada sebelah kiri (langsung di blog) merupakan tampilan blog apabila dibuka dengan menggunakan computer dan di sebelah kanan (seluler) merupakan tampilan blog apabila diakses dengan menggunakan handphone. 
Mulai dengan tema dasar lalu sesuaikan latar, tata letak, warna, font, dan lainnya..

Langsung di Blog

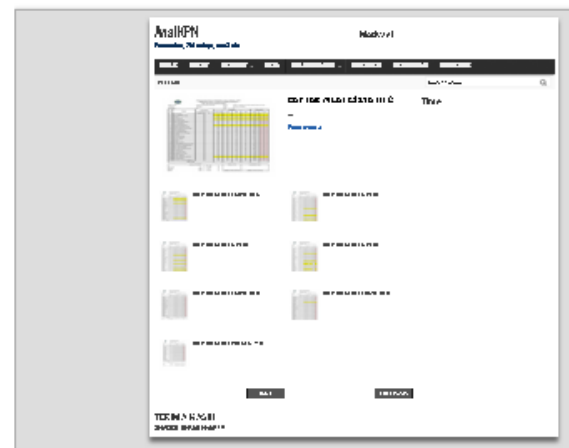

Sesuaikan

\section{Seluler}

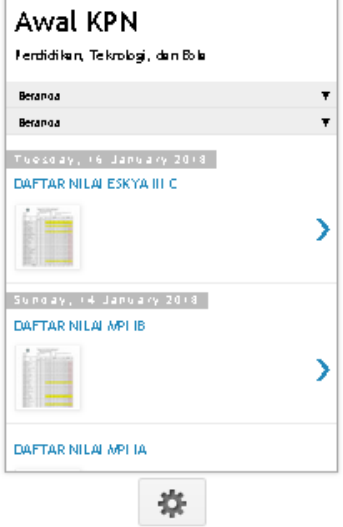

- Menu Setelan merupakan menu yang digunakan untuk mengatur setelan blog, disini dapat mengedit judul dari blog, deskripsi blog, dan alamat blog.

Dasar

Judul

Deskripsi

Privasi

Publikasi

Alamat Blog

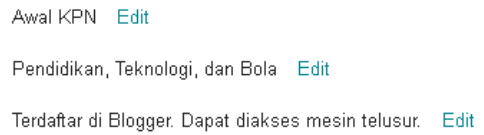

Setelah selesai membuat blog, langkah selanjutnya adalah mengganti tema yang berguna untuk mempercantik tampilan dari blog yang dibuat. Tema yang akan digunakan pada blog, dapat didownload terlebih dahulu pada situs-situs yang telah menyediakan tema blog secara gratis. Berikut ini beberapa alamat penyedia tema blog: 
- https://gooyaabitemplates.com/

- https://btemplates.com/

- http://www.mybloggerthemes.com/

- http://www.themexpose.com/

- http://www.protemplateslab.com/

- http://www.deluxetemplates.net/

Apabila tema blog telah selesai di download, selanjutnya pilihlah menu Tema pada dashboard blog.

$\boxminus$ Tata Letak

담

\section{Setelan}

Pada bagian kanan akan muncul halaman untuk mengganti tema dari blog

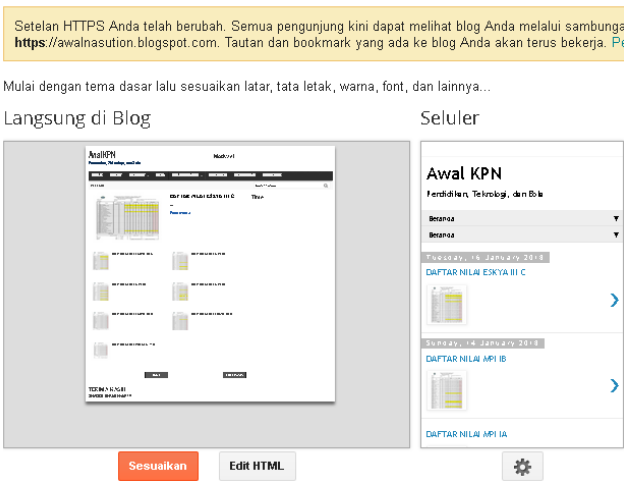

Selanjutnya pilihlah menu Backup/Pulihkan pada sudut kanan atas halaman edit tema.

Backup / Pulihkan

Kemudian akan muncul halaman Tema 


\section{Tema > Backup / Pulihkan}

Download backup tema Anda. Beberapa gadget mungkin tidak di-backup. ?

\section{Download tema}

Upload tema dari file di hard drive Anda.

(1) Tema khusus yang mencampur HTTP dan HTTPS dapat memengaruhi keamanan dan pengalaman pengguna blog Anda jika dilihat melalui HTTPS. Pelajari lebih lanjut. Browse... No file selected.

Upload

Pilihlah menu download tema untuk mendownload tema yang akan digunakan atau pilih menu Browse untuk memilih tema dari komputer yaitu tema yang telah didownload pada situs penyedia tema blog. Langkah selanjutnya adalah pilih menu Upload, maka otomatis tema blog akan diterapkan.

Setelah mengganti tema blog, biasanya menu-menu akan tampil secara default atau bawaan, baik itu bentuk dan namanya.

\section{EDUBLOG}

HOME BUSINESS * DOMNLOADS * PARENT CATEGORY * FEATURED

\section{BLOGGER TEMPLATES}

\section{PAGES}

$\Rightarrow$ Beranda

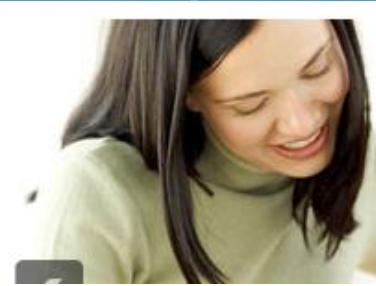

Untuk menyesuaikan nama-nama menu sesuai dengan tema postingan, perlu dilakukan proses edit dari nama menu tersebut, caranya sebagai berikut:

Masuklah ke halaman dashboard dan pilih tombol tema, 


\section{Tata Letak}

Tema

Setelan

Maka akan muncul halaman tema di sebelah kanan dari tombol tema, lanjunkan dengan memilih tombol Edit HTML.

Langsung di Blog

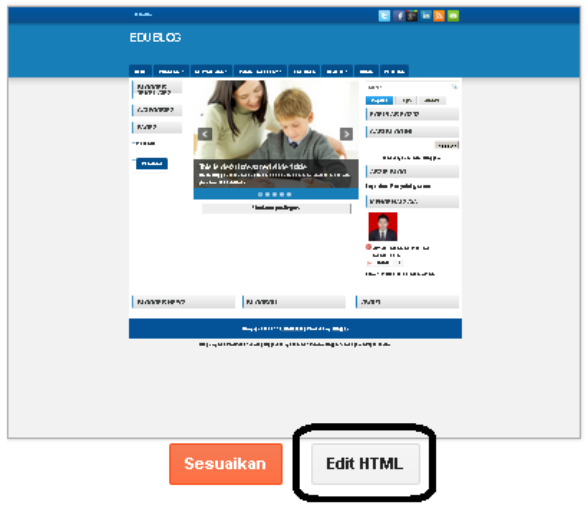

Seluler

\section{EDUBLOG}

Berangs

Berangs

Beranas

Tidakada poati ron

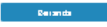

viat wers wot

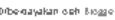

$\operatorname{los}$

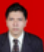

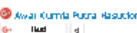

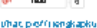

Maka akan muncul halaman edit HTML seperti berikut ini: Sembunyikan peringatan

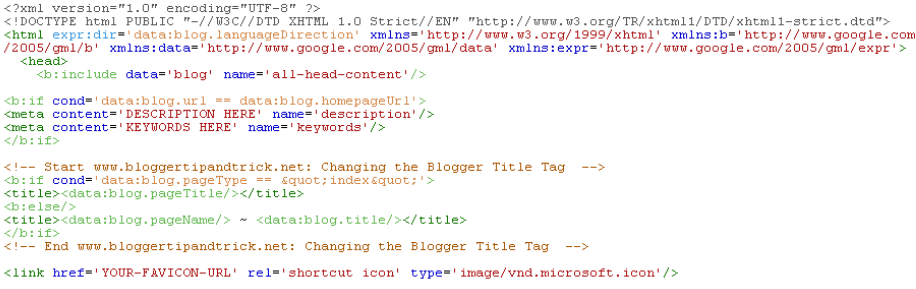

Kemudian pada keyboard tekan tombol Ctrl dan F, sehingga muncul jendela pencarian di sebelah kanan atas halaman edit HTML. 
\begin{tabular}{|l|l|l} 
Format tema Kembalikan perubahan & Kembalikan tema widget ke default
\end{tabular}

pengalaman pengguna blog Anda jika dilihat melalui HTTPS. Pelajari lebih lanjut.

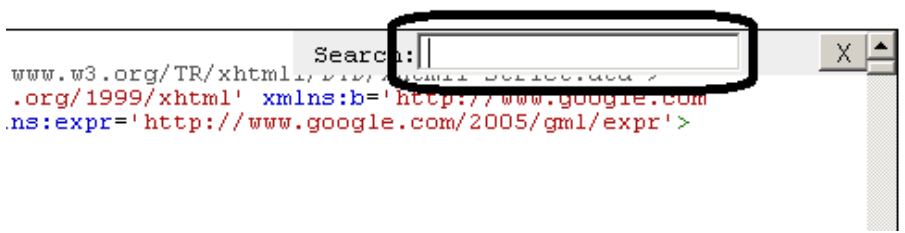

Lanjutkan dengan mengetik kata sesuai menu yang akan dirubah, misalnya pada contoh ini akan dirubah nama menu BUSINESS menjadi pendidikan.

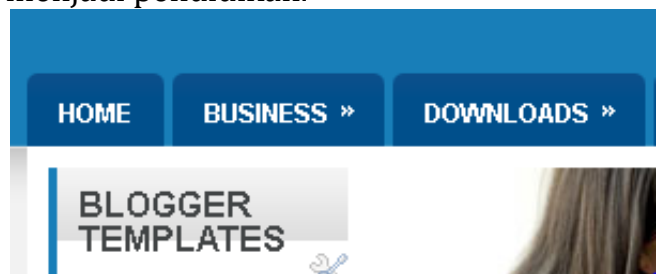

Maka ketik pada jendela pencarian BUSINESS, lalu tekan enter.

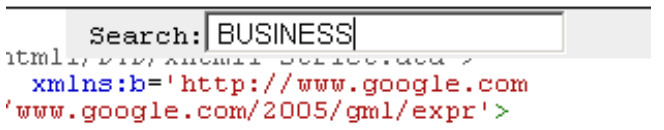

Kemudian pada halaman edit HTML akan muncul kata BUSINESS,

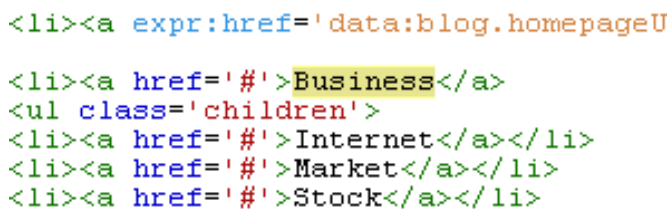

Ubahlah kata BUSINESS menjadi kata PENDIDIKAN. 
〈ul class='menus menu-secondary'>

$<l i><a$ expr:href=' data:blog. homepageU1

$\langle 1$ i $\rangle\langle a$ href='\#'>PENDIDIKHNk $/ a\rangle$

<ul class='children'>

$\langle 1$ i $\rangle\langle a$ href='\#' $\rangle$ Internet $\langle/ a\rangle\langle/ 1\rangle$

$\langle 1$ i $\rangle\langle a$ href='\#' $>$ Market $\langle/ a\rangle\langle/ 1$ i $\rangle$

$\langle 1$ i $>\langle a$ href='\#'>Stock $\langle/ a\rangle\langle/ 1\rangle$

Setelah selsai, pilihlah tombol simpan tema.

\begin{tabular}{l} 
Kembali \\
Simpan tema \\
\hline Mengedit tema sehingga dapat mencampur HTTP d \\
Sembunyikan peringatan
\end{tabular}

789 〈div class='span-24'〉

Apabila tahap demi tahap dilakukan dengan benar, maka menu BUSINESS pada halaman blog akan berubah menjadi PENDIDIKAN.

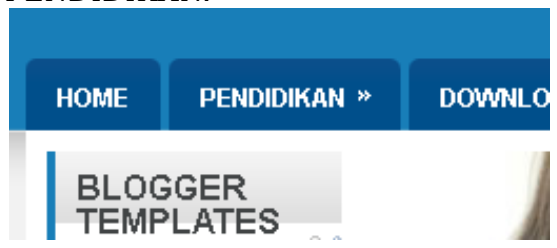

Menu yang tersedia pada blog juga dapat ditambah, apabila dirasa menu yang sudah ada masih kurang. Caranya sebagai berikut:

Masuklah kehalaman edit HTML seperti saat proses mengganti nama tema, kemudian pilih tombol Ctrl dan F pada Keyboard. Ketiklah pada halaman pencarian STOCK, kemudian tekan enter, maka akan muncul kata pendidikan pada halaman edit HTML.

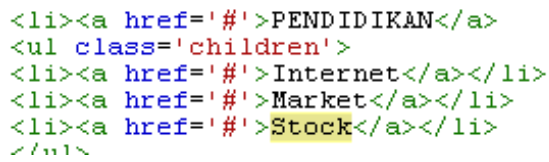

Pada contoh ini akan ditambahkan menu baru dengan nama BUKU akan dibuat di bawah menu stock. 


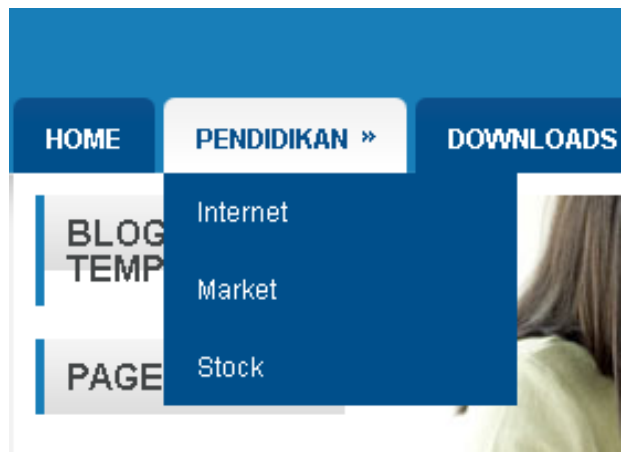

Proses selanjutnya copylah semua huruf pada kata stock dari awal sampai akhir, kemudian paste tepat di bawah baris kata stock, sehingga ada 2 baris yang serupa.

$\langle 1$ i $\rangle\langle a$ href='\#'>Internet $\langle/ a\rangle\langle/ 1 i\rangle$

$\langle 1 i\rangle\langle a$ href='\#'>Market $\langle/ a\rangle\langle/ 1\rangle$

$\langle 1 i><a$ href='\#'>Stock $\langle/ a\rangle</ 1 i>$

$<1 i><a$ href='\#'>Stock $</ a></ 1 i>1$

$</$ ul>

$\langle/ 1$ i>

Lanjutkan mengubah kata STOCK yang baris kedua menjadi BUKU.

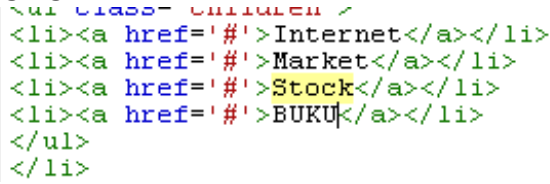

Kemudian tekan tombol simpan tema, maka otomatis akan mucul menu baru di bawah menu STOCK.

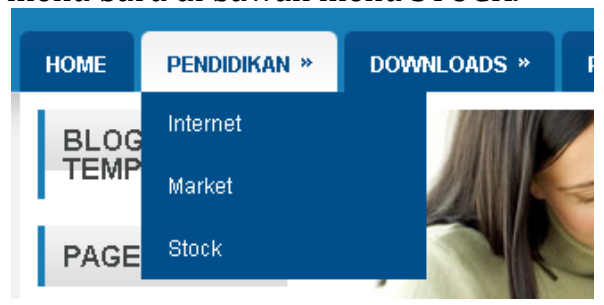

PEMANFAATAN Blog SEBAGAi MEDiA PEMBELAJARAN 
Pemanfaatan blog sebagai media pembelajaran dengan memanfaatkan fitur-fitur yang telah disediakan oleh blogspot.com. Fitur-fitur yang telah disediakan inilah yang akan dioptimalisasikan agar tercapai tujuan blog sebagai media pembelajaran. Berikut ini beberapa cara memanfaatkan blog sebagai media pembelajaran.

1. Membuat artikel materi pelajaran

Untuk membuat artikel tentang materi pelajaran, ada baiknya bila terlebih dahulu mempersiapkan materi yang akan diposting. Apabila materi telah disiapkan maka masuklah ke halaman dashboard blogspot. Kemudian pilihlah menu entri baru.

B Blogger Awal KPN -

Lihat blog

트 Postingan

Semua (34)

Draf (1)

Diterbitkan (33)

II. Statistik

\section{Semua postingan}

\section{Entri baru}

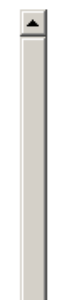

Setelan HTTPS Anda telah berubah. Semua pengunjung kini https:/awalnasution. blogspot.com. Tautan dan bookmark yar

Г Publikasikan Kembali ke draf

Г DAFTAR NILAI ESKYA III C Aphikasikomputer

Akan muncul halaman tempat untuk membuat artikel di blogspot, seperti berikut ini:

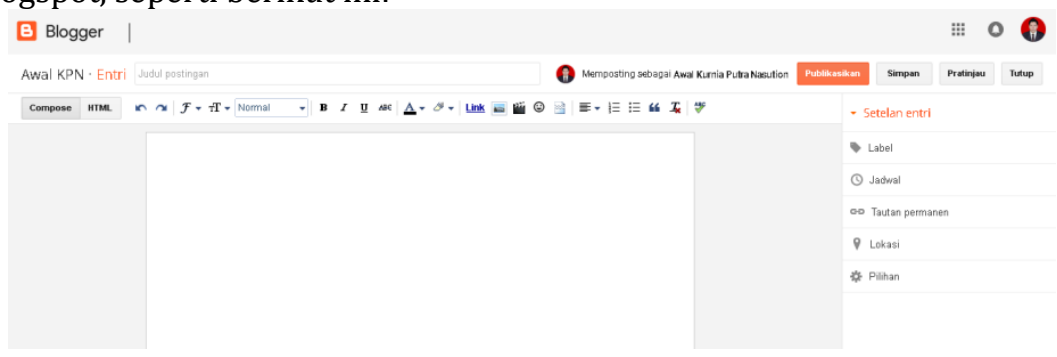

Berikut ini kegunaan dari berbagai menu:

- Menu Judul artikel adalah tempat untuk menulis Judul materi pelajaran yang akan di posting.

- Label digunakan untuk member nama label dari artikel yang berguna untuk mengelompokkan artikel-artikel sejenis.

- Jadwal digunakan untuk mengatur waktu tayang artikel. 
- Pilihan digunakan untuk mengatur apakah pembaca boleh komentar atau tidak, format teks/HTML, dan pengaturan pindah baris.

- Publikasikan berguna untuk mempublish artikel yang telah dibuat

- Simpan digunakan untuk menyimpan artikel yang telah di buat tanpa mempublish artikel tersebut

- Pratinjau digunakan untuk melihat hasil tampilan artikel yang kita buat tanpa mempublish

Untuk membuat artikel, terlebih dahulu membuat judul dari artikel tersebut pada kolom Judul Postingan.

\section{- Entri Pengertian dan Dimensi Kurikulum}

Setelah selesai membuat judul, selanjutnya ketiklah artikel pada kolom artikel seperti gambar berikut ini:

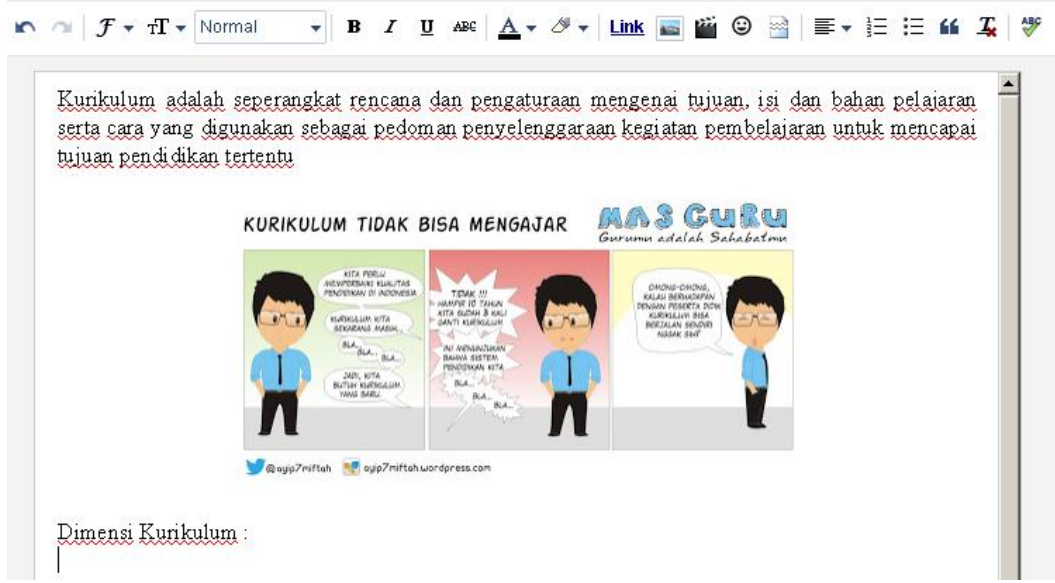

Apabila sudah selesai mengetik atau membuat artikel, selanjutnya pilih label dan berilah label dari artikel yang akan dipublish, kalau mau melihat bagaimana hasil dari artikel yang telah di buat pilih pratinjau. Setelah semua selesai, lanjutkan dengan memilih menu Publikasikan untuk mempublish artikel yang telah dibuat.

2. Memasukkan gambar kedalam artikel 
Untuk memberi keterangan yang lebih detail ataupun menarik dari sebuah artikel, perlu untuk memasukkan gambar pada artikel tersebut. Caranya adalah sebagai berikut:

Pilihlah menu Insert Image
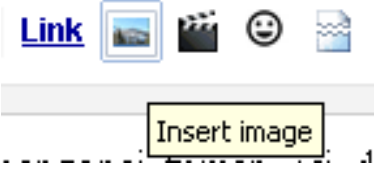

Akan munul halaman Add Image kemudian pilih menu Pilih file, pilihlah gambar yang akan di masukkan ke dalam artikel dari computer. Setelah selesai memilih gambar, tunggulah sampai gambar tersebut selesai di upload. Apabila proses upload telah selesai, pilihalah gambar tersebut dan lanjutkan dengan memilih menu Add Selected.

3. Memasukkan video ke dalam artikel

Pada beberapa artikel, ada saatnya memerlukan video di dalam artikel yang akan dibuat. Kegunaannya untuk memberi keterangan yang lebih detail terhadap sebuah postingan, bisa berupa tutorial atau yang lainnya.

Pilihlah menu Insert a Video

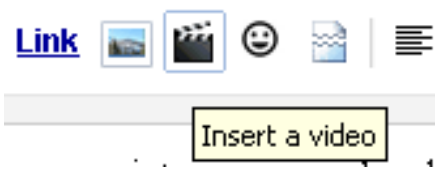

Akan muncul halaman Add a Video, akan muncul tiga pilihan:

Add a Video

Upload From YouTube My YouTube videos 
- Upload digunakan apabila video yang akan dimasukkan kedalam artikel berasal dari komputer. Untuk menggunakan pilihan ini pilihlah menu Pilih Video untuk diupload kemudian pilihlah video yang berasal dari computer untuk di upload, tunggulah sampai proses upload selesai.

\section{Tarik video ke sini}

Ata $\sqcup_{1}$ jîka Anda maப...

\section{Pilih video untuk diupload}

- From YouTube digunakan apabila video yang akan dimasukkan ke dalam artikel berasal dari situs https://www.youtube.com/. Untuk menggunakan pilihan ini copy lah terlebih dahulu link dari video yang berasal dari youtube kemudian pastekan pada kolom yang disediakan.

\section{Tarik video ke sini}

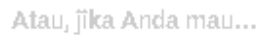

Pilih vidas untuk diupload

- My YouTube videos digunakan apabila video yang akan dimasukkan ke dalam artikel berasal dari chanel youtube yang kita miliki.

Apabila proses memilih video sudah selesai, lanjutkan dengan menekan menu Pilih.

4. Memasukkan link ke dalam artikel

Memasukkan link ke dalam sebuah artikel berguna untuk memberi referensi tambahan pada artikel yang dibuat.

Pilihlah menu Add or Remove Link 


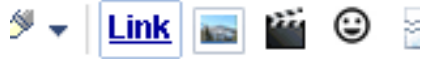 \\ Add or remove link}

Akan muncul halaman Edit Link

\begin{tabular}{|c|c|}
\hline Edit Link & $\times$ \\
\hline \multicolumn{2}{|l|}{ Text to display: } \\
\hline Link to: & To what URL should this link go? \\
\hline \multicolumn{2}{|l|}{ (c) Web address } \\
\hline \multirow[t]{2}{*}{$\mathrm{Email}$ address } & Test this link \\
\hline & $\begin{array}{l}\text { Not sure what to put in the box? First, find the page on the } \\
\text { web that you want to link to. ( } A \text { search engine might be useful.) } \\
\text { Then, copy the web address from the box in your browser's } \\
\text { address bar, and paste it into the box above. }\end{array}$ \\
\hline 『 Open this link in & window \\
\hline
\end{tabular}

OK Cancel

Masukkan alamat link yang akan dimasukkan ke dalam artikel pada kolom Web address, setelah selesai pilih menu OK.

Link yang akan dibagikan atau di publish di artikel dapat juga menggunakan tulisan sendiri dalam bentuk pdf. Untuk dapat melakukan hal ini, terlebih dahulu file yang akan di bagikan/share di upload ke google drive. Berikut ini cara mengupload file ke google drive. Pertama masuklah ke dalam google drive dengan mengakses https://www.google.com/drive/ kemudian pilih Go To Google Drive. 


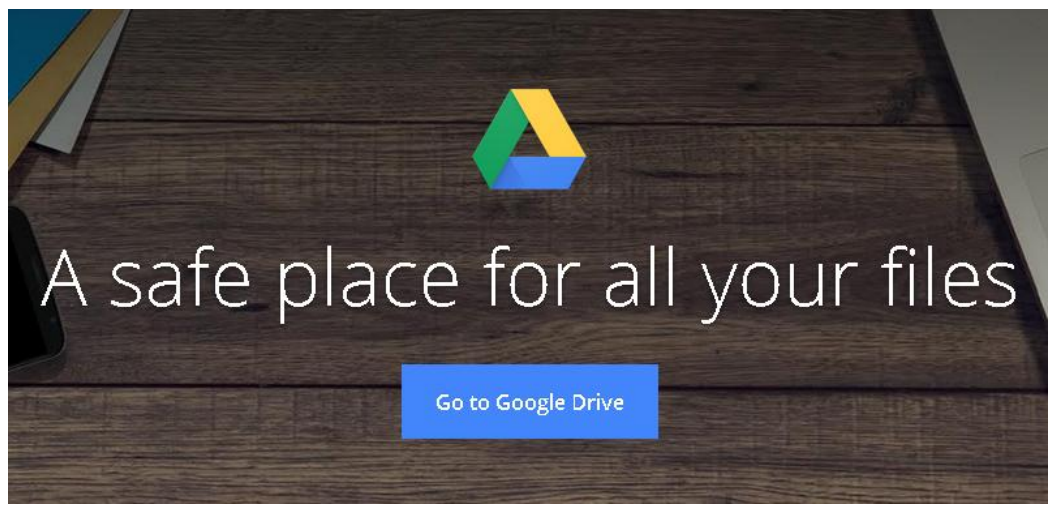

Selanjutnya login menggunakan akun email dari google.

Sign in to continue to Google Drive

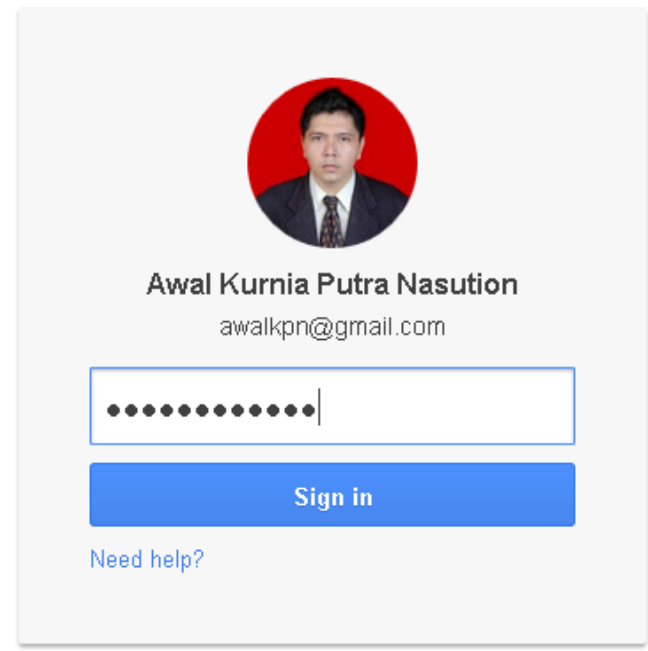

Akan muncul halaman google drive 


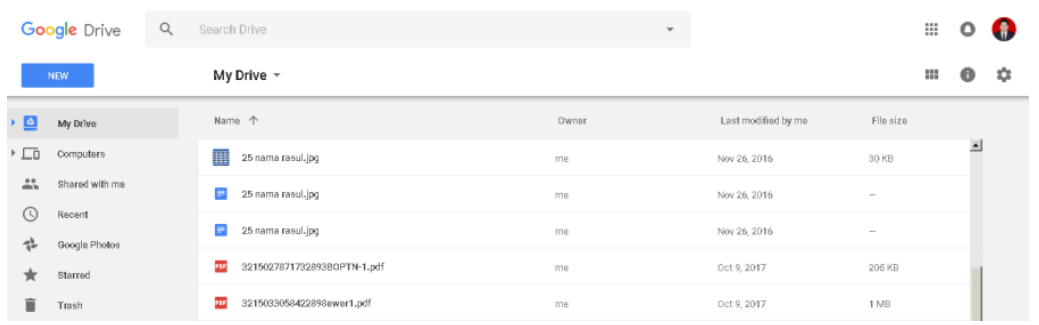

Selanjutnya pilih menu New maka akan muncul pilihan Folder, File Upload, dan Folder upload. Pilihlah menu File upload.

\section{Google Drive Q Search Drive}

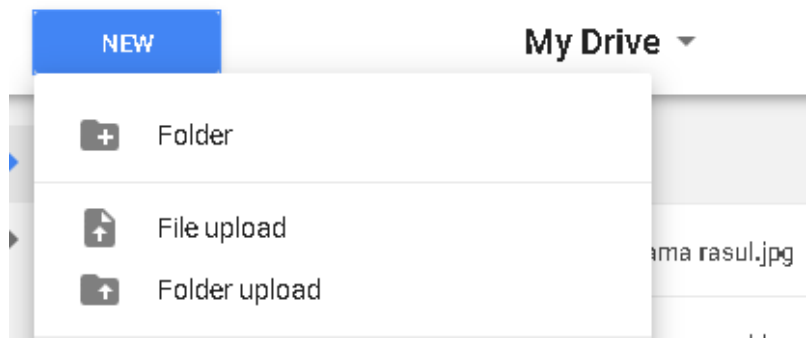

Kemudian akan muncul halaman memilih file yang akan di upload, pilihlah file dan tekan open.

\begin{tabular}{|c|c|c|c|}
\hline \multirow{2}{*}{ Recent Places } & Name - & Date modified & | Type \\
\hline & $\Xi$ MPI III rev_Page_1 & $15 / 01 / 201812: 05$ & JPEG image \\
\hline$\square \sqrt{\text { Libraries }}$ & $E$ MPI III rev_Page_2 & $15 / 01 / 201812: 05$ & JPEG image \\
\hline † Documents & DDEF MPI III & 15/01/2018 8:10 & Foxit Reader PDF C \\
\hline $\pm d \hat{l}$ Music & EMPI III_Page_1 & $15 / 01 / 20188: 34$ & JPEG image \\
\hline$\boxplus \boxminus$ Pictures & EMPI III_Page_2 & $15 / 01 / 20188: 34$ & JPEG image \\
\hline 甲国 videos & 빨 nilai tahsin & $11 / 01 / 20188: 58$ & Microsoft Office Exı \\
\hline -W Computer & $\equiv$ PAIVA & $15 / 01 / 20188: 22$ & JPEG image \\
\hline$\pm \Leftrightarrow$ Local Disk (C:) & DDF PAI VA & $15 / 01 / 20188: 22$ & Foxit Reader PDF C \\
\hline$\boxplus \boxminus$ Local Disk (D:) & $E \mathrm{PAI} \cup \mathrm{B}$ & $15 / 01 / 20188: 23$ & JPEG image \\
\hline & BDA PAI V B & $15 / 01 / 20188: 08$ & Foxit Reader PDF C \\
\hline \multirow[t]{3}{*}{ † Network } & & & $\perp$ \\
\hline & \multirow[t]{2}{*}{ File name: PAIVB } & All Files & $\nabla$ \\
\hline & & Open & Cancel \\
\hline
\end{tabular}

Tunggu sampai file selesai diupload, waktu proses upload data dipengaruhi oleh besar atau kecilnya file dan kecepatan internet. 


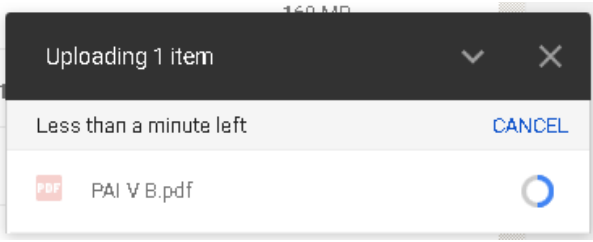

Selesai proses upload ditandai dengan sudah ditemukannya file di dalam google drive.

PDF NETP16.pdf

Untuk menambahkan link kedalam sebuah artikel yang berasal dari google drive, terlebih dahulu mengcopy alamat url dari file tersebut. Caranya dengan pilih file dan klik kanan pada file tersebut dengan menggunakan mouse, kemudian pilihlah tombol Get shareable link.

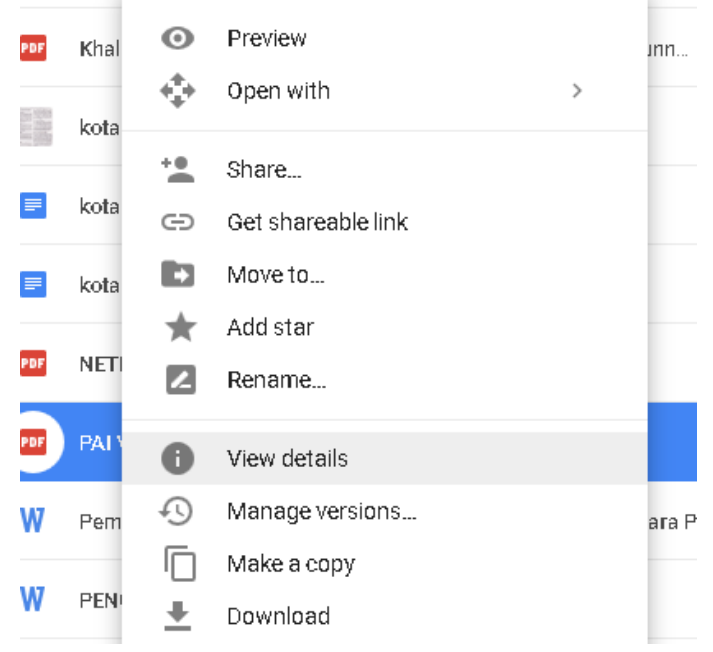


Maka link alamat url dari file akan tercopy secara otomatis dan langsung dapat di paste ke halaman edit link.

\section{Edit Link}

Text to display: https://driwe.google.com/open?id=1I9Emm3UwdMf5jSb7sDFe5fFr

Link to:

To what URL should this link go?

c Web address Jm/open?id=1I9Emm3UwdMf5jSb7sDFe5fFnOAtF1qH4

Email address $\underline{\text { Test this link }}$ 


\section{BAB III}

\section{FACEBOOK SEBAGAI MEDIA PEMBELAJARAN}

\section{Pengertian FACEBOOK}

Facebook adalah salah satu situs jejaring sosial yang sudah cukup dikenal dan merupakan yang terbesar untuk saat ini. Hampir semua pengguna internet pasti mengetahui facebook atau bahkan memiliki account facebook. ${ }^{12}$ Facebook saat ini sudah sangat terkenal dan banyak digunakan sebagai alat bersosialisasi. Facebook merupakan salah satu media social yang sangat digemari di Indonesia, hal ini berdasarkan data pada tahun 2017 bahwa Indonesia merupakan pengguna facebook terbesar keempat teraktif didunia dengan 115 juta pengguna aktif. ${ }^{13}$

Laju penggunaan facebook semakin meningkat terus, bahkan facebook sekarang tidak hanya digunakan oleh kalangan dewasa tetapi juga pada kalangan pelajar dan mahasiswa. Tingginya angka penggunaan facebook dalam kehidupan sehari-hari dapat dimanfaatkan sebagai salah satu alternative media pembelajaran yang digunakan dalam menunjang proses pembelajaran di sekolah dan di perkuliahan.

\section{Cara Membuat AKun Facebook}

Agar dapat menggunakan facebook sebagai media pembelajaran, terlebih dahulu harus membuat akun facebook. Berikut ini beberapa tahap untuk membuat akun facebook. Langkah awal untuk membuat akun facebook adalah dengan membuka website https://www.facebook.com/. Akan muncul halaman awal facebook yang berisikan form pendaftaran seperti yang terdapat pada gambar dibawah ini, isilah sesuai identitas.

${ }^{12}$ Oya Suryana dan Matamaya Studio, Membanggun Blog Wordpress. (Jakarta, PT elex Media Komputindo, 2008).

13 http://tekno.liputan6.com/read/2926217/indonesia-negara-ke-4dengan-pengguna-facebook-teraktif-di-dunia 


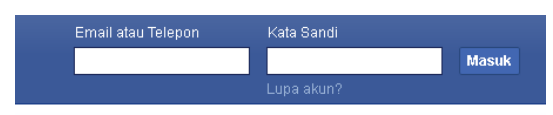

\section{Daftar}

Gratis, sampai kapan pun.

\begin{tabular}{|c|c|}
\hline Nama depan & Nama belakang \\
\hline \multicolumn{2}{|l|}{ Nomor seluler atau email } \\
\hline \multicolumn{2}{|l|}{ Kata sandi baru } \\
\hline \multicolumn{2}{|l|}{ Ulang Tahun } \\
\hline $2 \quad \forall$ Feb $\quad 1993$ & $\begin{array}{l}\text { - Mengapa saya harus } \\
\text { memberikan tanggal lahir } \\
\text { saya? }\end{array}$ \\
\hline$C$ Perempuan $C$ Laki- & laki \\
\hline $\begin{array}{l}\text { Dengan mengkilik Buat Akun, maka Anda s } \\
\text { kani dan bahwwa Anda sudah membaca K } \\
\text { termasuk Penggunaan cookie kami. Anda } \\
\text { Pembertahuan SMS dari Facebook dan da } \\
\text { saja. }\end{array}$ & $\begin{array}{l}\text { cetuju dengan Ketentuan } \\
\text { ebijakan Data kami, } \\
\text { akan menerima }\end{array}$ \\
\hline Buat Akun & \\
\hline
\end{tabular}

Apabila semua data yang diperlukan selesai dibuat, pilihlah menu "Buat Akun". Akan muncul tiga langkah mudah untuk memulai facebook. Langkah pertama yaitu menambahkan orang yang mungkin anda kenal sebagai teman. Pilihlah mencari teman nanti, jadi pilih Selanjutnya.

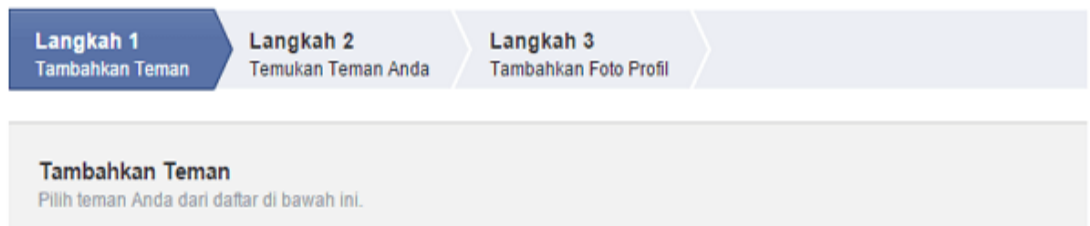

Untuk langkah yang kedua hampir sama dengan langkah yang pertama yaitu menambahkan teman. Bedanya, pada langkah ini dapat mencari teman melalui daftar email. Silakan pilih Selanjutnya, kemudian pilih Lewati langkah. 


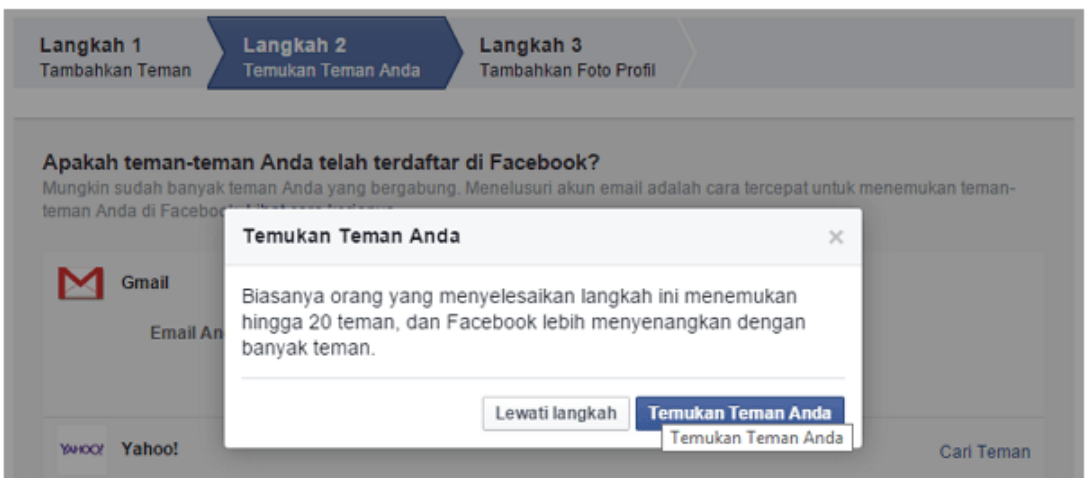

Langkah ke tiga adalah mengganti foto profil, pilihlah salah satu foto dan pilih Selanjutnya.

Langkah 1

Tambahkan Teman
Langkah 2

Temukan Teman Anda
Langkah 3

Tambahkan Foto Profil

\section{Atur foto profil Anda}

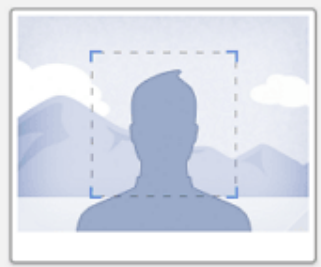

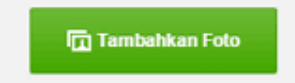

ATAU

Ambil Foto

Dengan kamera web Anda

218 30+

Ada lebih dari 30 orang bemama Muchammad Zakaria di Facebook Tambahkan foto profil sehingga teman-teman Anda mengetahui bahwa itu Anda.

Untuk tahap terakhir pembuatan akun facebook, harus konfirmasi akun. Buka email yang didaftarkan pada halaman awal facebook dan pilihlah email yang berasal dari facebook, kemudian klik tombol "Konfirmasi Akun Anda".Akan muncul notifikasi bahwa anda sudah dikonfirmasi. 
Hai Muchammad,

Anda baru saja mendaftar Facebook. Untuk menyelesaikan pendaftaran Facebook, harap konfirmasikan akun Anda.

Konfirmasi Akun Anda

\section{PEMANFAATAN FACEBOOK SEBAGAI MEDIA PEMBELAJARAN}

Pemanfaatan facebook sebagai media pembelajaran adalah dengan memanfaatkan menu Grup Facebook yang telah disediakan halaman facebook. Penggunaan grup facebook sebagai media pembelajaran dengan cara membuat virtual class. Facebook sebagai virtual class (kelas maya) sudah mulai banyak digunakan saat ini sebagai alternative pengganti pembelajaran yang dilaksanakan dikelas. Pembelajaran dikelas yang berupa tatap muka tidak bisa digantikan sepenuhnya dengan virtual class, tapi antara pembelajaran dikelas dan pembelajaran dengan memanfaatkan virtual class dapat dipadukan agar menghasilkan pembelajaran yang lebih maksimal. ${ }^{14}$ Virtual class atau yang sering juga disebut dengan kelas maya merupakan kelas yang antara guru dan siswa tidak bertatap muka langsung di kelas seperti biasa, tetapi proses tatap muka diganti dengan kelas yang komunikasinya dengan memanfaatkan internet sebagai media. Kelas maya ini terlebih dahulu dibuat oleh guru, dimana guru menyediakan forum bagi penerima bahan ajar dan melakukan diskusi serta kegiatan belajar mengajar di kelas.

Untuk dapat memenfaatkan facebook sebagai media pembelajaran, terlebih dahulu harus membuat grup facebook. Berikut ini langkah-langkah membuat grup facebook.

1. Langkah-langkah membuat Grup Facebook

a. Apabila telah memiliki akun Facebook, selanjutnya login ke halaman utama Facebook dengan mengisi email dan password terlebih dahulu kemudian tekan masuk.

\footnotetext{
${ }^{14}$ Awal Kurnia Putra Nasution, Penggunaan Grup Facebook Sebagai Virtual Class. (Aceh, Jurnal Assalam, 2017).
} 


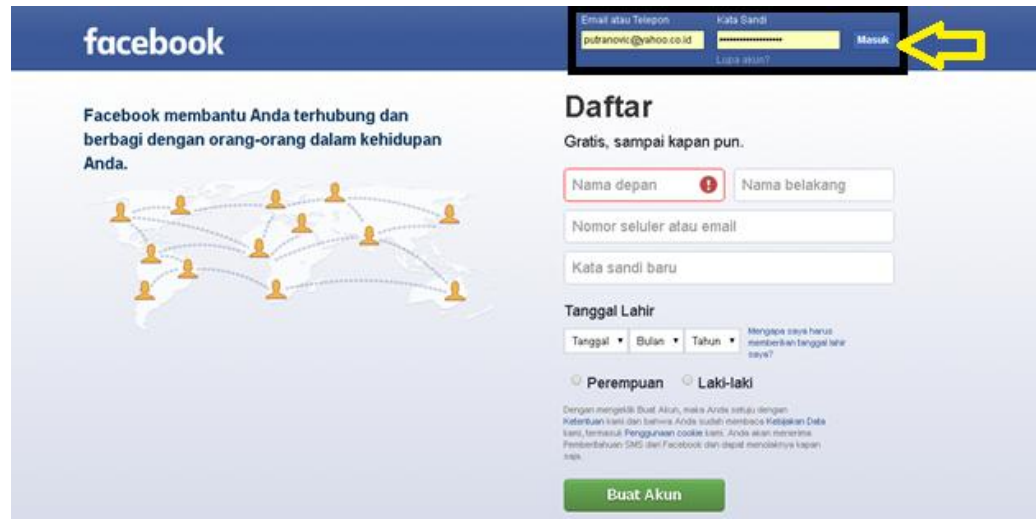

b. Selanjutnya buatlah grup dengan menekan ikon grup

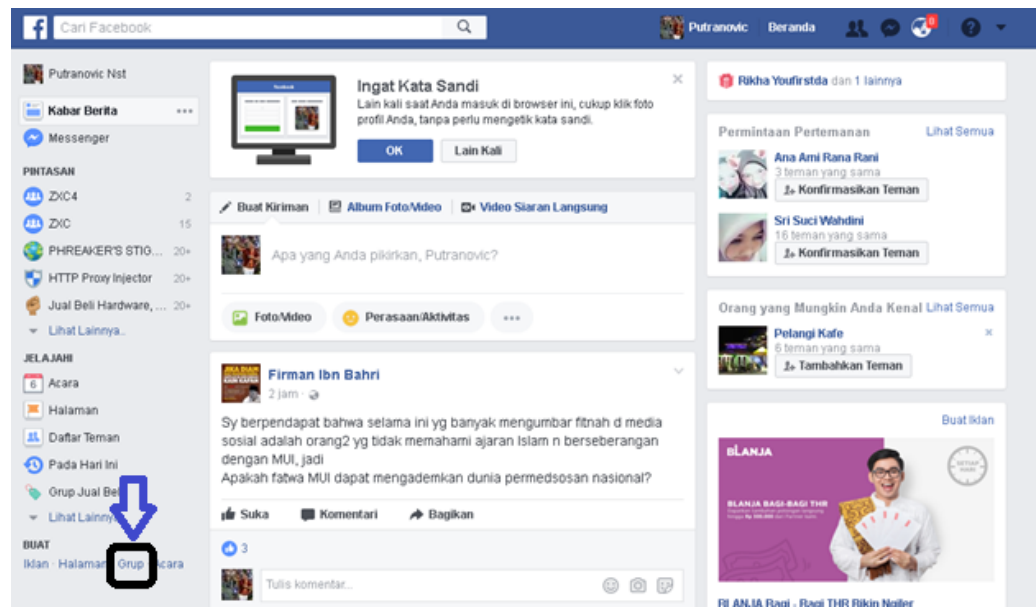

c. Akan muncul kotak untuk membuat nama grup, isikan sesuai dengan nama grup yang akan dibuat dan tambahkan juga beberapa orang anggota grup yang merupakan mahasiswa yang akan menjadi anggota virtual class dan tekan ikon buat. 


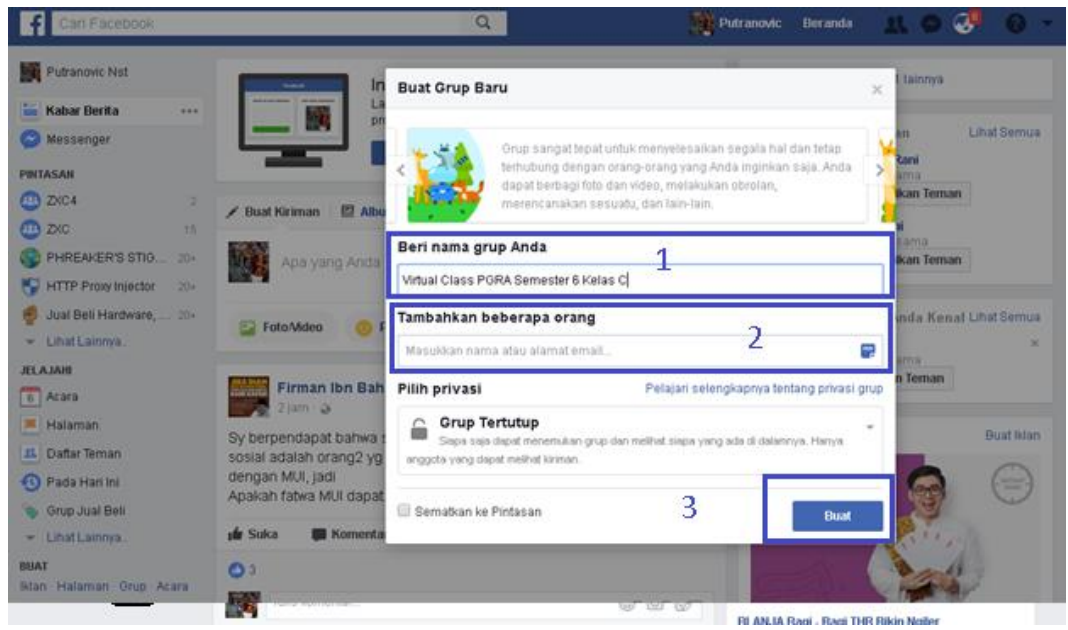

d. Apabila grup telah dibuat maka akan terlihat tampilan seperti berikut ini:

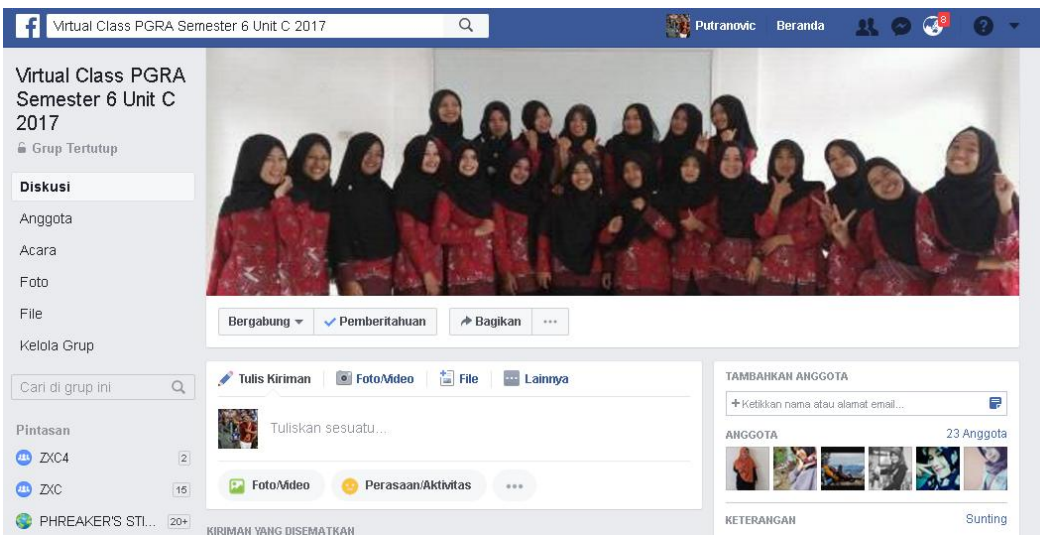

e. Gambar profil grup dapat diganti sesuai dengan kebutuhan. 


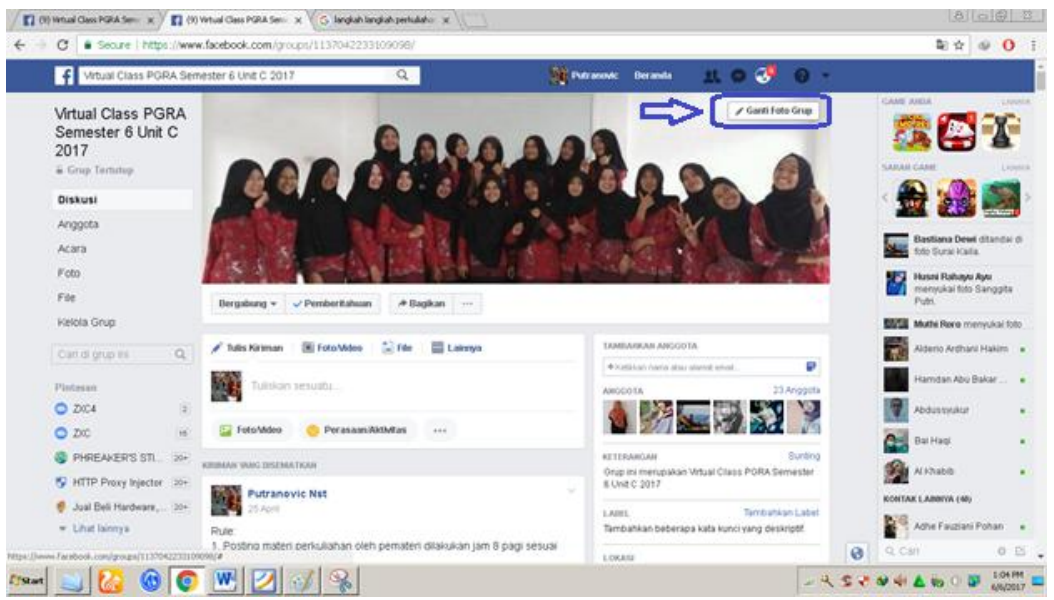

f. Agar semua mahasiswa dapat masuk ke grup, langkah selanjutnya adalah dengan menambahkan anggota dengan cara menekan tanda + di bawah kolom Tambahkan Anggota.

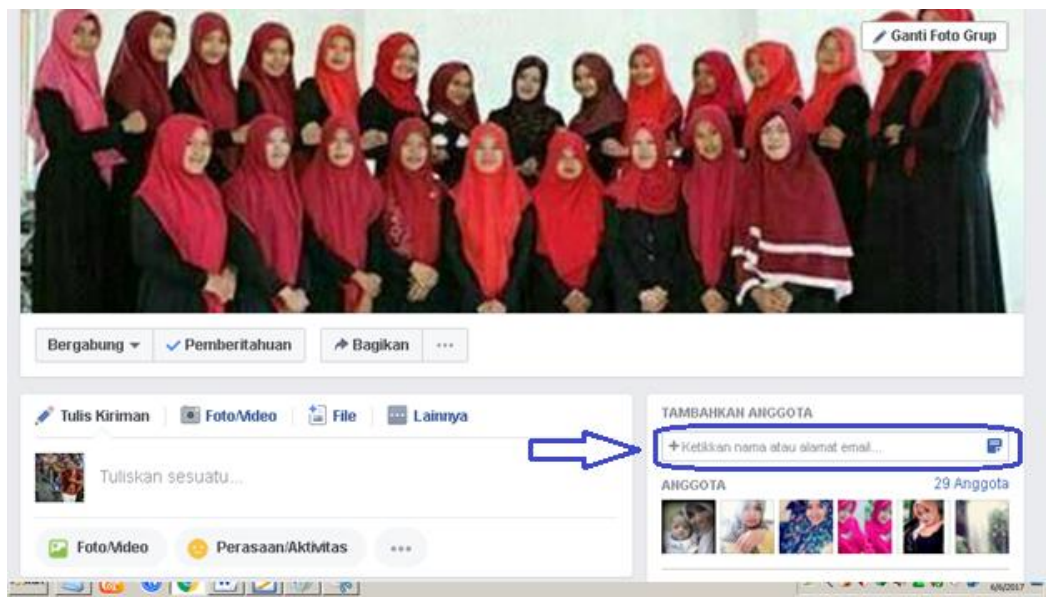

g. Agar perkuliahan yang akan dilakukan di virtual class berjalan dengan teratur dan maksimal ada baiknya membuat aturan grup dengan cara membuat tulisan/postingan Rule yang kemudian disematkan. 


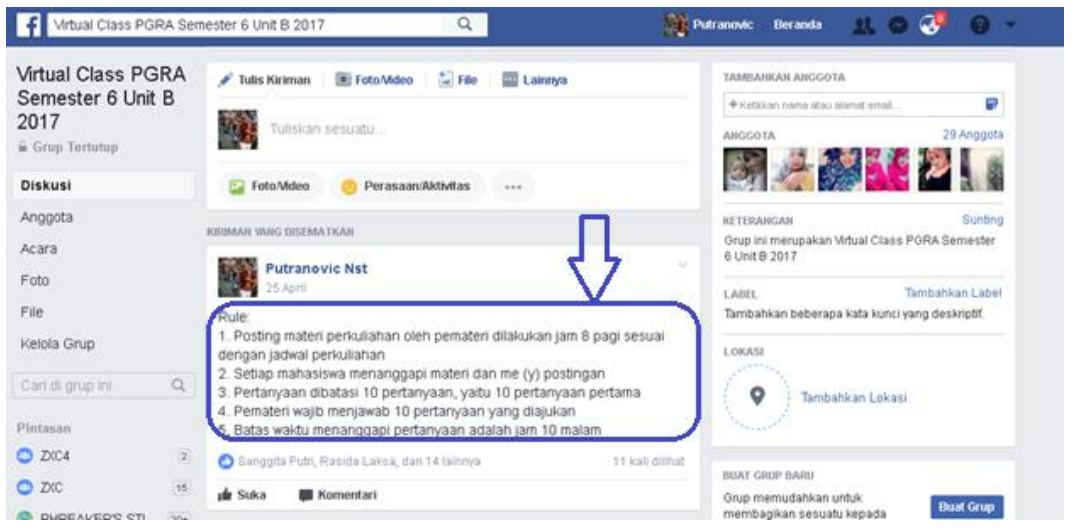

h. Langkah selanjutnya adalah dengan mengisi keterangan grup, agar grup memiliki keterangan yang lebih lengkap.

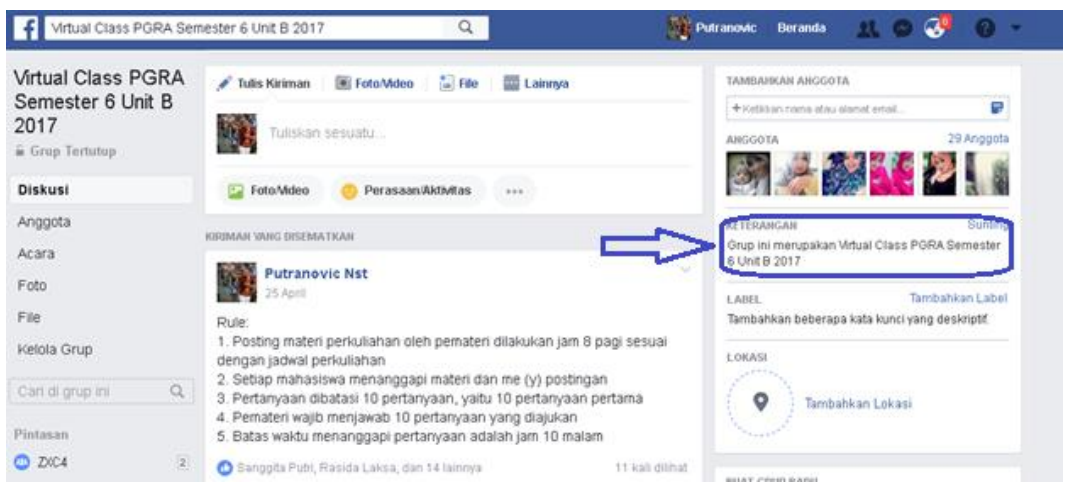

i. Setelah grup terbentuk dan rule telah dibuat, maka perkuliahan sudah dapat dimulai dengan mengikuti jadwal sesuai dengan jadwal perkuliahan regular.

2. Desain Grup Facebook sebagai Virtual Class

Desain Grup Facebook sebagai virtual class dapat dilihat seperti gambar berikut ini: 
Gambar 1. Desain Grup Facebook sebagai Virtual Class (Anggara: 2013) ${ }^{15}$

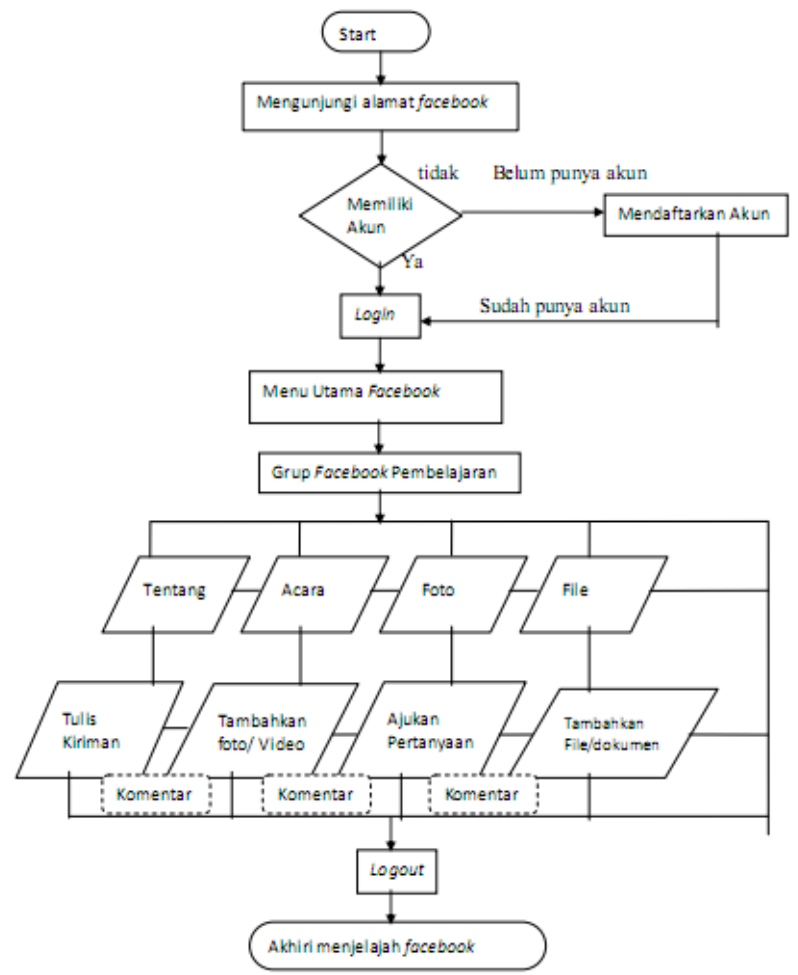

${ }^{15}$ Anggara, Agung Melisa, Pemanfaatan Jejaring Sosial Melalui Grup Dalam Facebook Sebagai Sarana Pengelolaan Pembelajaran Pada Mata Pelajaran Teknologi Informasi Dan Komunikasi Kelas X Sma (Siswa Kelas X6 Dan X7 Sman 1 Banjarharjo - Brebes). (Semarang, Universitas Negeri Semarang, 2013). 
3. Pengelolaan Perkuliahan

Pengelolaan perkuliahan terdiri dari beberapa tahap, yaitu:

a. Tahap pertama pada perkuliahan dengan virtual class ini dimulai dengan membuat postingan atau komentar tentang resume materi perkuliahan yang dilengkapi dengan nama kelompok dan nama anggota kelompok.

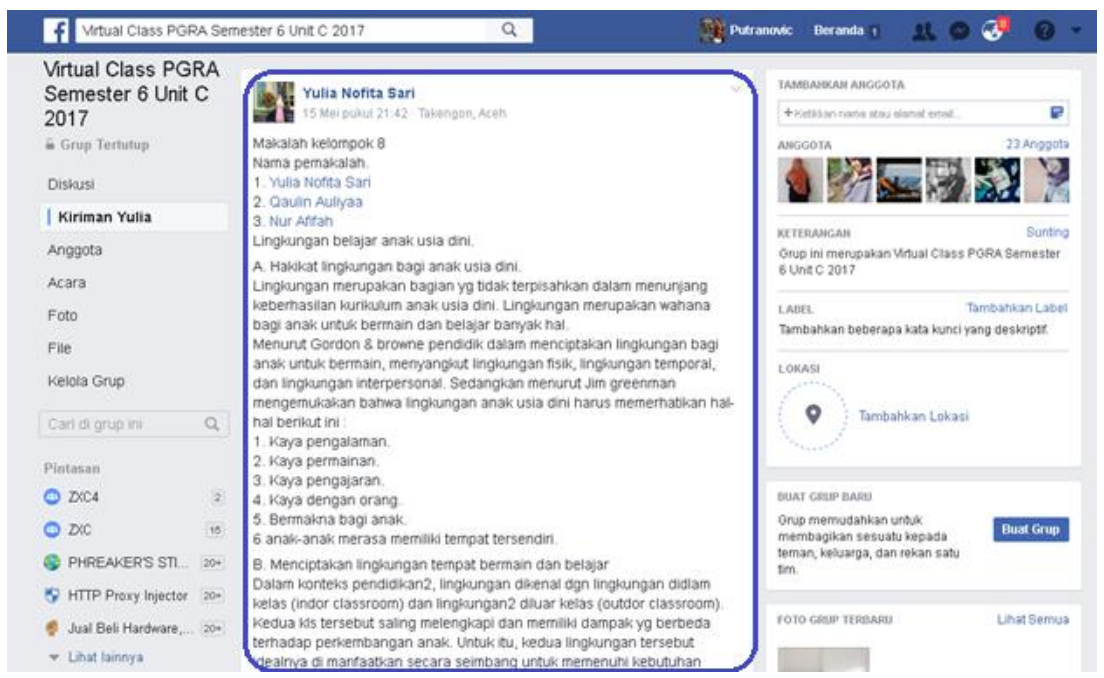

b. Tahap kedua, seluruh anggota grup dipersilahkan untuk melike, menanggapi, dan bertanya tentang materi postingan pertanda bahwa mahasiswa tersebut hadir didalam kelas. 

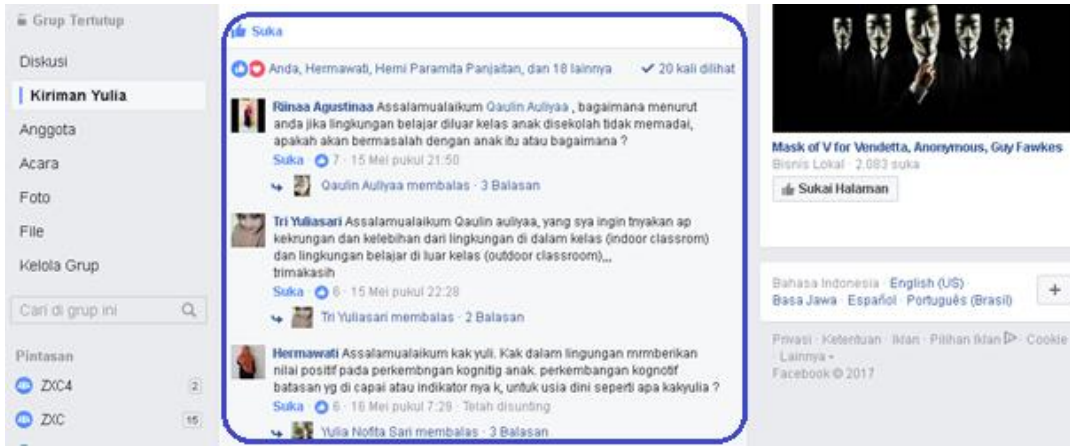

Mask of $\mathrm{V}$ tor Vendetta, Anonymous, Guy Fawkes

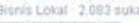

Tukas Hataman

Bahusa indonesia English (US:

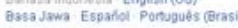

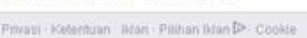

Facebook o 2017

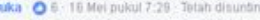

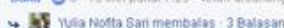

c. Tahap ketiga, pemateri memiliki kewajiban untuk menjawab 10 pertanyaan pertama yang terdapat di kolom komentar. Pada tahap ini penanya dikolom komentar juga boleh menanggapi ulang jawaban dari pemateri, baik berupa tanda setuju terhadap jawaban atau bahkan menolak jawaban pemateri. Pada tahap ini dosen bertugas untuk mengawasi jalannya diskusi antara mahasiswa dan memberikan jawaban yang lebih baik apabila diperlukan.

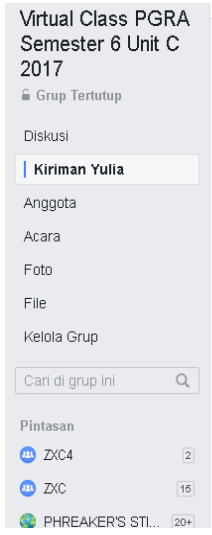

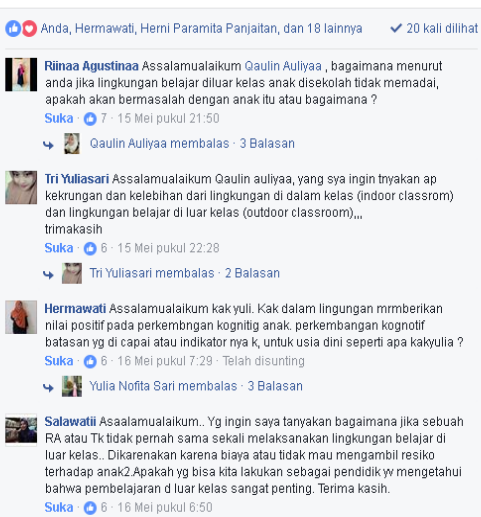
anda jika lingkungan belajar diluar kelas anak disekolah tidak memadai, apakah akan bermasalah dengan anak itu atau bagaimana? Suka : 7 : 15 Mei pukul $21: 50$

Tri Yuliasari Assalamualaikum Qaulin auliyaa, yang sya ingin tnyakan ap kekrungan dan kelebihan dari lingkungan di dalam kelas (indoor classrom) dan lingkungan belajar di luar kelas (outdoor classroom)... trimakasin

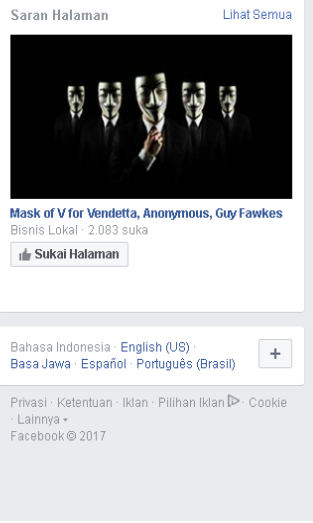

d. Tahap keempat, setelah waktu untuk diskusi selesai, dosen membuat komentar tentang materi postingan, kemudian dosen sebagai moderator menonaktifkan komentar pada postingan materi sekaligus membuat rekapitulasi perkuliahan pada hari tersebut. 


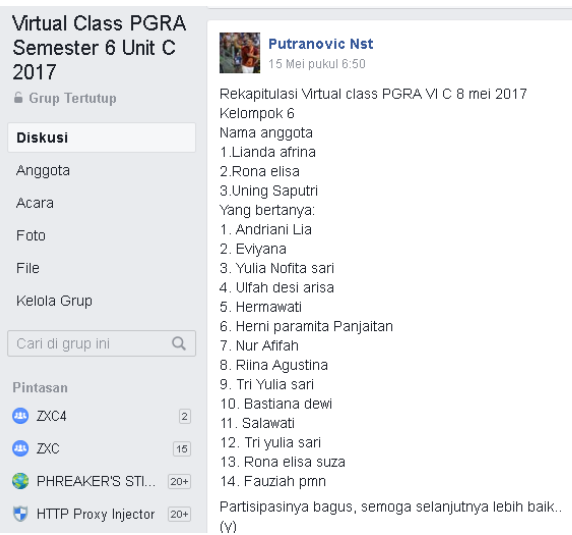

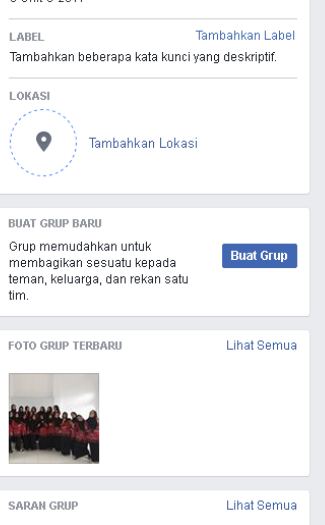




\section{BAB IV}

\section{WHATSAPP SEBAGAI MEDIA PEMBELAJARAN}

\section{PENGERTIAN WHATSAPP}

Whatsapp merupakan salah satu aplikasi media sosial yang sangat banyak digunakan dewasa ini, hal ini didukung dengan fakta bahwa pengguna aktif whatsapp saat ini lebih dari 1 miliar orang. Kegunaan utama dari whatsapp ini sendiri pada awalnya adalah untuk menghubungkan antara teman dan keluarga setiap saat. Whatsapp dapat digunakan untuk mengirimkan pesan dan melakukan panggilan yang aman.

WhatsApp didirikan oleh Jan Koum dan Brian Acton yang sebelumnya telah menghabiskan 20 tahun di Yahoo. WhatsApp bergabung dengan Facebook pada tahun 2014, namun terus beroperasi sebagai aplikasi terpisah dengan fokus laser untuk membangun layanan perpesanan yang bekerja cepat dan andal di manapun di dunia. WhatsApp dimulai sebagai alternatif SMS. Produk kami sekarang mendukung pengiriman dan penerimaan berbagai media: teks, foto, video, dokumen, dan lokasi, serta panggilan suara. Pesan dan panggilan kami dijamin dengan enkripsi end-to-end, yang berarti bahwa tidak ada pihak ketiga termasuk WhatsApp yang bisa membaca atau mendengarkannya. Di balik setiap keputusan produk adalah keinginan kita untuk membiarkan orang berkomunikasi di manapun di dunia tanpa hambatan. ${ }^{16}$

Untuk menggunakan aplikasi whatsapp, ada beberapa langkah yang harus dilakukan, yaitu:

1) Mengunduh aplikasi whastapp melalui playstore

2) Menginstal aplikasi whatsapp di phonsel

3) Mendaftarkan nomor telephon

4) Menerima kode konfirmasi kemudian menkonfirmasi kode

${ }^{16}$ https://www.whatsapp.com/about/ 
Whatsapp memiliki bermacam-macam fitur yang disedikan untuk semua pengguna, yaitu :
1) Pesan
2) Chat Grup
3) Panggilan Suara dan Video
4) Membagikan Dokumen
5) Pesan Suara

\section{Cara Membuat Akun Whatsapp}

Cara membuat akun whatsapp di android

1. Download aplikasi Whatsapp secara gratis melalui Google PlayStore.

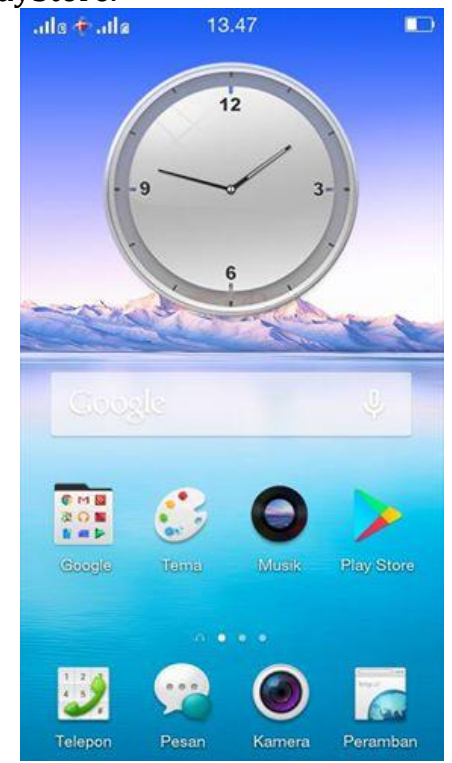

2. Instal aplikasi whatsapp di perangkat hp android 


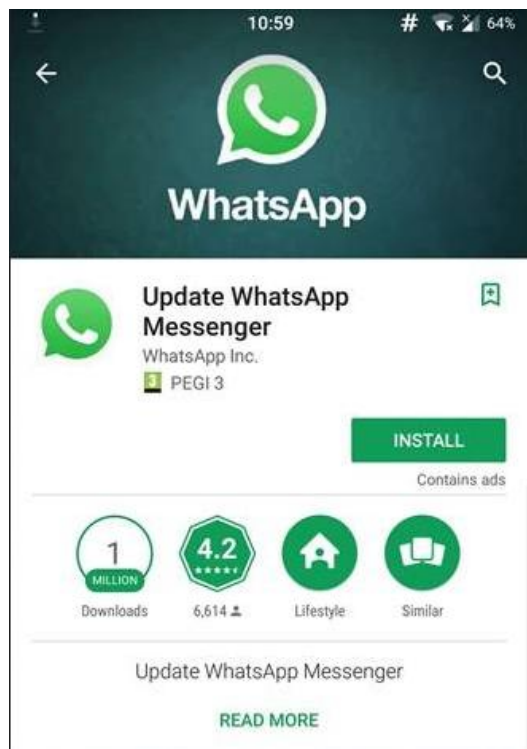

3. Buka aplikasi whatsapp pada android, maka akan muncul halaman selamat datang dengan informasi mengenai whatsapp yang mendukung cross platform. Pilih pada Agree and Continue.

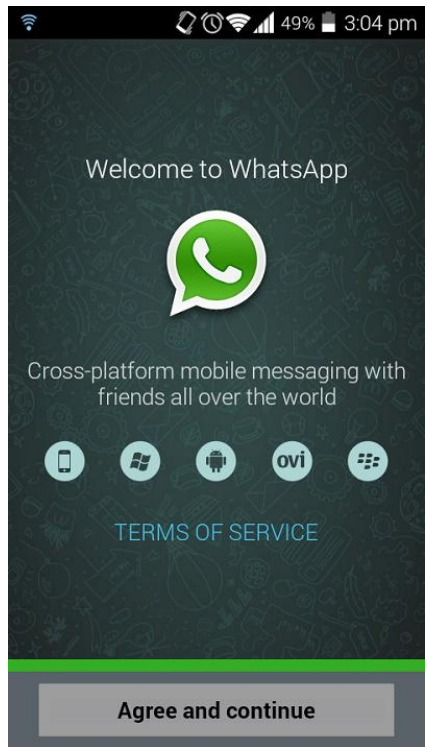


4. Langkah selanjutnya adalah memasukkan nomor telepon yang akan didaftarkan pada WhatsApp. Tap pada OK untuk menuju proses selanjutnya.

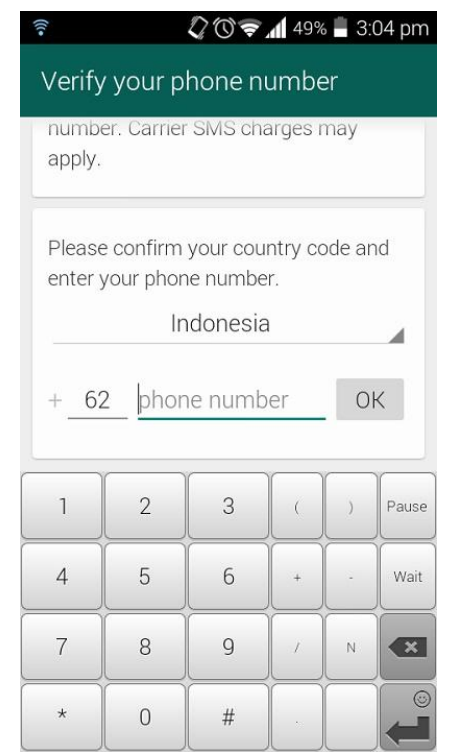

5. Jendela konfirmasi nomor telepon akan muncul. Nomor telepon bias diubah jika ingin menggunakan nomor lain atau melakukan koreksi, dan juga bisa langsung melakukan tap pada OK untuk menuju proses berikutnya. 


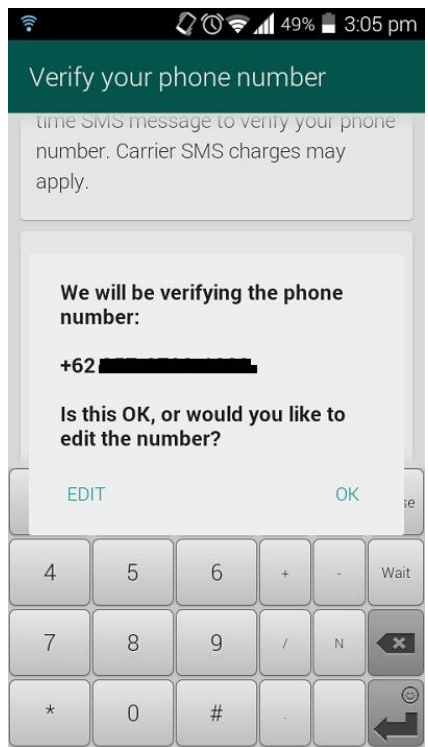

6. Proses berikutnya adalah menunggu kode konfirmasi yang dikirim oleh WhatsApp, nomor telepon masih bias diedit pada tahap ini. Jika kode konfirmasi yang dikirim whatsapp sudah sampai, maka anda akan langsung dikirim ke proses selanjutnya. 


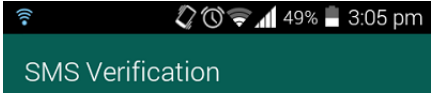

Waiting to automatically detect an

SMS sent to

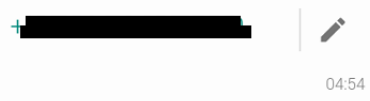

Please make sure you have a working

SMS plan.

Sit back and relax. We'll notify you

when we're done verifying.

7. Berikutnya adalah proses pemberian nama dan foto profil. Penggunaan nama bias menggunakan nama lengkap atau hanya inisial saja, dan untuk foto profil bisa mengambilnya dari gallery.

$\begin{array}{ll}.110+.11 \text { a } & 14.01 \\ \leftarrow \quad \text { Profil }\end{array}$

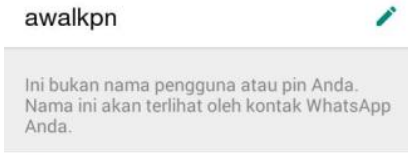

Info dan nomor telepon

Hey there! I am using WhatsApp. 
8. Akun Whatsapp sudah selesai dibuat dan siap dipakai, akan muncul 3 pilihan yaitu : CHATTING yang berisi daftar, baik itu group chat maupun chat dengan individu, STATUS yang berisi status pribadi maupun status teman, dan PANGGILAN yang berisi daftar panggilan masuk dan keluar.

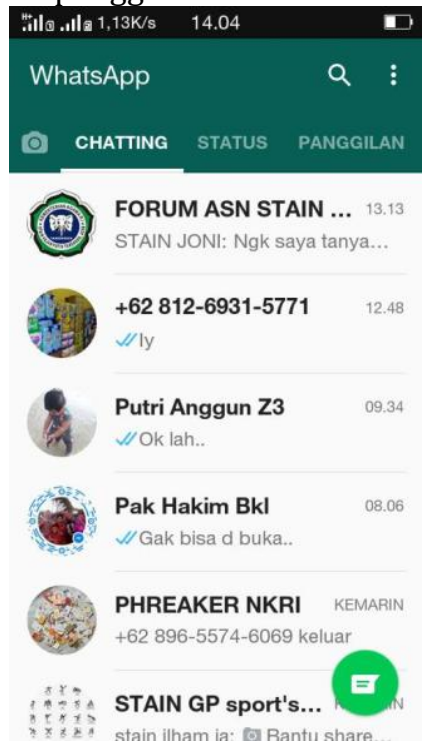

PEMANFAATAN WHATSAPP SEBAGAI MEDIA PEMBELAJARAN

Pemanfaatan whatsapp sebagai media pembelajaran yaitu dengan memanfaatkan fitur grup whatsapp yang tersedia pada aplikasi whatsapp. Grup whatsapp digunakan untuk membuat Virtual class. Virtual Class (kelas maya) inilah yang akan menjadi media pembelajaran. Cara membuat grup di whatsapp :

1. Buka WhatsApp dan kunjungi layar daftar Chatting. 

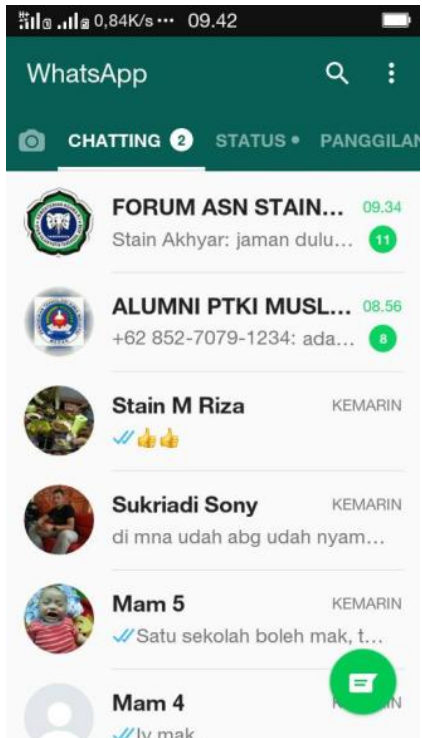

2. Pada bagian atas layar daftar Chatting, ketuk tombol Grup Baru. Catatan: Anda harus memiliki sebuah chat sebelum membuat sebuah Chat Grup baru.

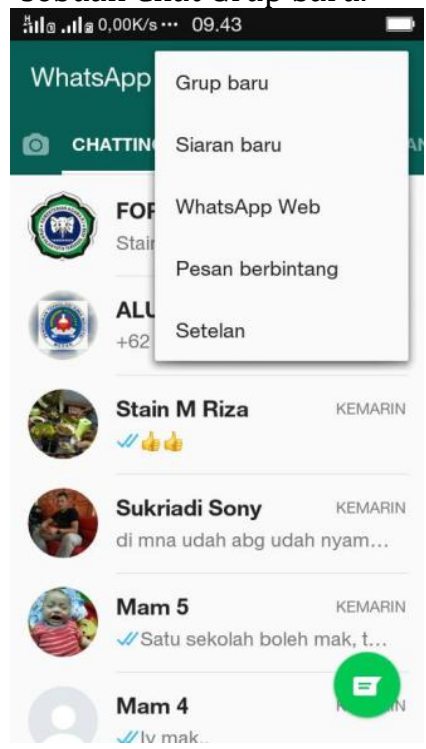


3. Tambahkan peserta grup dengan memilih atau mengetik nama kontak. Ketuk Berikutnya sesudah selesai menambahkan peserta.

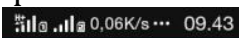

$\leftarrow \quad$ Grup baru

Tambah peserta

Q

\section{8 afhdal}

Hey there! I am using What...

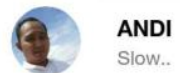

Slow..

\section{ANDRI NST}

Hey there! I am using What...

\section{ANSOR NST}

Bismillah,., walhamdulillah,.,

ARFAN 03

Ada

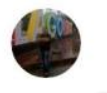

Arihman Barus

4ㅇ. $\Delta$ viı Fi vo

4. Tambahkan ikon untuk grup dengan mengetuk kotak foto yang kosong. Ini akan ditampilkan di samping grup di daftar Chatting Anda. 


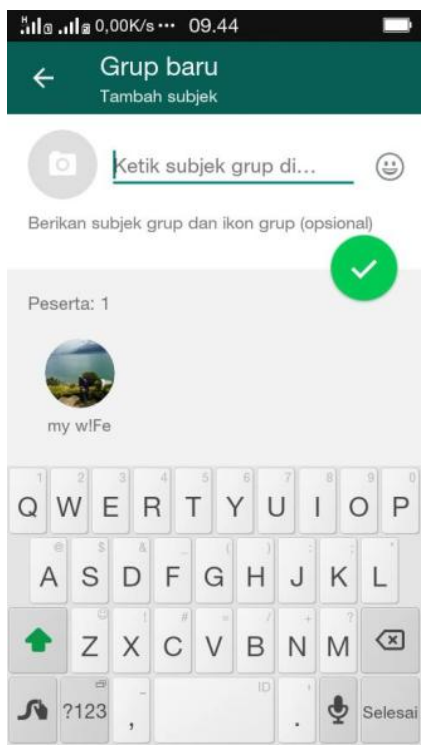

5. Tambahkan sebuah subjek grup, ini bisa juga diisi dengan nama grup yang akan dibuat.

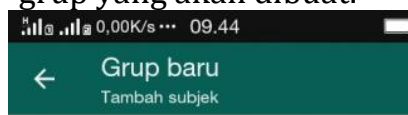

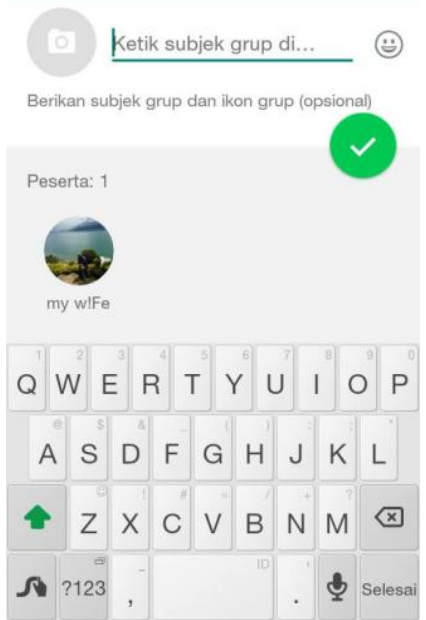

6. Ketuk Buat setelah telah selesaimembuat subjek grup. 


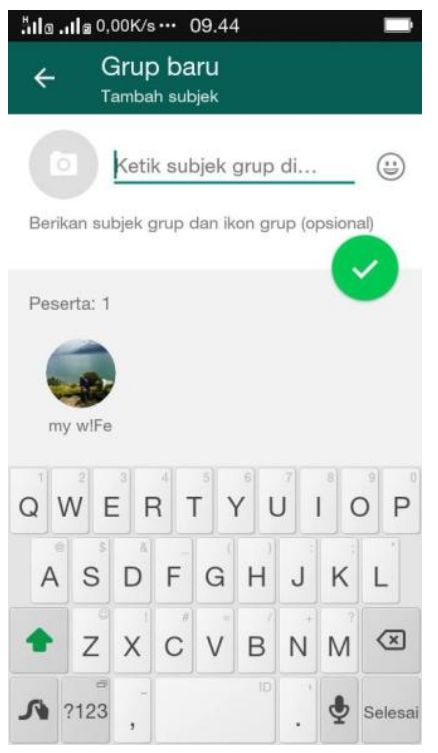

Setelah tahap membuat grup sudah selesai, langkah selanjutnya adalah dengan menambahkan semua anggota kelas kedalam grup. Langkah-langkah untuk menambahkan anggota grup sebagai berikut:

1. Buka grup di WhatsApp, kemudian ketuk subjek grup. 
"illo alla 0,00K/s»09.57

$\leftarrow$ MYOB EKSYA UNIT A...

Komti, $+62821-6764-0292,+62 \ldots$

A Pesan-pesan yang dikirim ke grup ini kini diamankan dengan enkripsi end-to-end.

Ketuk untuk info selengkapnya.

+62 822-7758-7354 membuat grup "MYOB EKSYA UNIT A SMT 3"

+62 822-7758-7354 telah menambahkan Anda

23 SEPTEMBER 2017

+62 822-7330-9745 keluar

+62 822-7758-7354 menambahkan +62 822-7330-9745

+62 822-7330-9745 -DedilrfanSayoga

Ok makasih yup

16.38

+62 822-7758-7354 -Wulan Dara Sari

(:) Ketik pesan is 0 (4)

2. Ketuk Tambahkan Peserta grup, peserta grup adalah semua mahasiswa yang ada di dalam kelas.

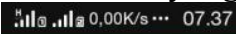

\section{\%1}

$\leftarrow$

$+\frac{1}{2}$

MYOB EKSYA

Dibuat oleh Anda, hari ini pada 07.36

Bisukan notifikasi

Notifikasi khusus

\section{Enkripsi}

Pesan-pesan yang dikirim ke grup in

diamankan dengan enkripsi end-to-

end. Ketuk untuk info selengkapnya.

2 peserta

+6 Tambahkan Peserta...

3. Cari atau pilih kontak yang ingin ditambahkan ke Chat Grup, kemudian ketuk Tambahkan. 


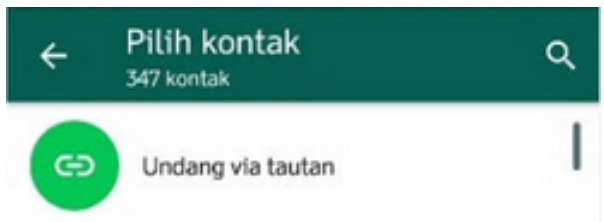

Dosen sebagai admin grup memulai kelas dengan membuat status tentang materi pelajaran.

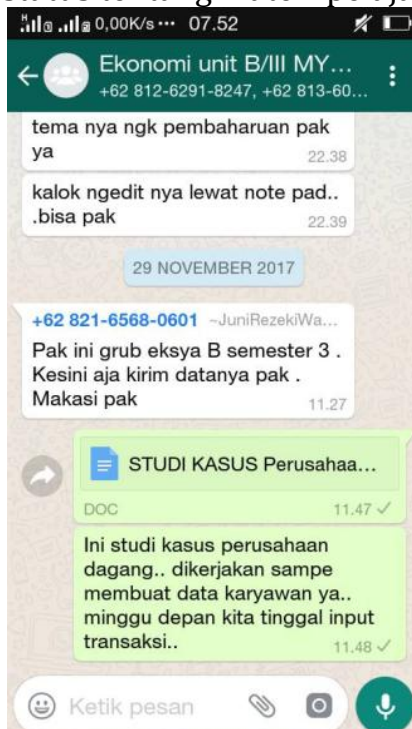

Materi pelajaran dapat dilengkapi dengan menambahkan file berupa pdf maupun word sebagai keterangan lebih lanjut. Caranya sebagai berikut :

- tekan tombol tambahkan file 


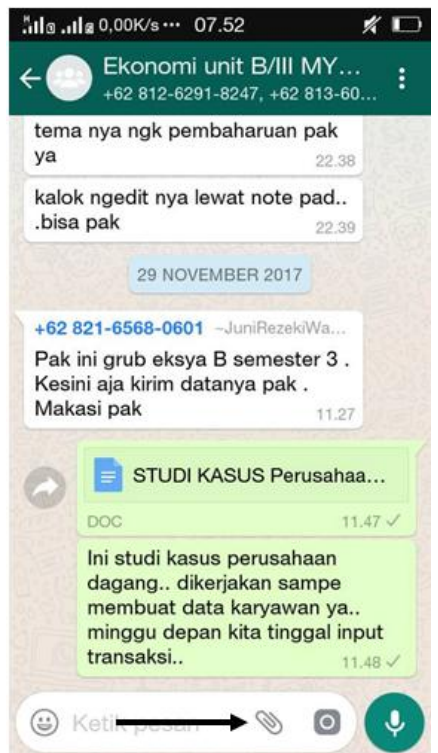

- Pilih tombol Dokumen untuk menambahkan file yang akan dilampirkan

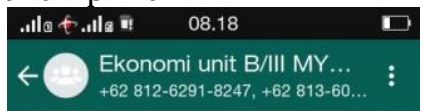

Pak ini grub eksya B semester 3 .

Kesini aja kirim datanya pak .

Makasi pak

STUDI KASUS Perusahaa...

DOC $11.47 \checkmark$

Ini studi kasus perusahaan dagang.. dikerjakan sampe

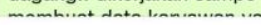

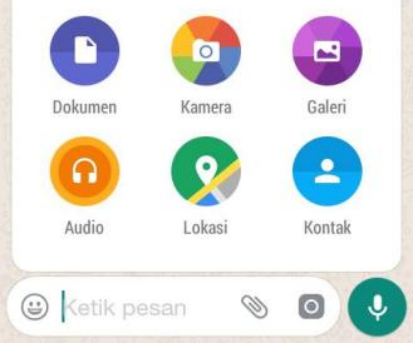

- kemudian pilih file yang akan ditambahkan 


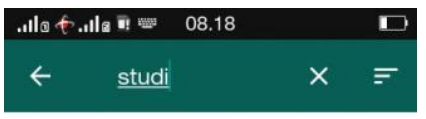

늘 Lihat dokumen lain...

= STUDI KASUS Perusahaan D... $69 \mathrm{~KB}$ $29 / 11 / 17$

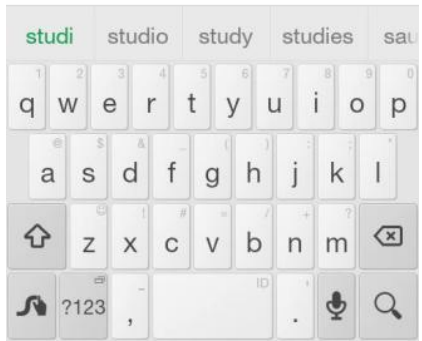

- Apabila file yang akan dilampirkan sudah benar kemudian tekan tombol Kirim

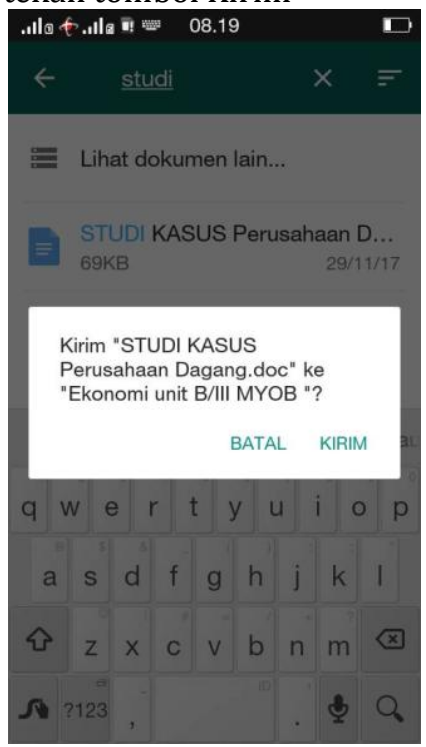


Materi pelajaran yang disampaikan dapat juga dilengkapi dengan melampirkan foto. Caranya sebagai berikut :

- Pilih tombol tambahkan foto

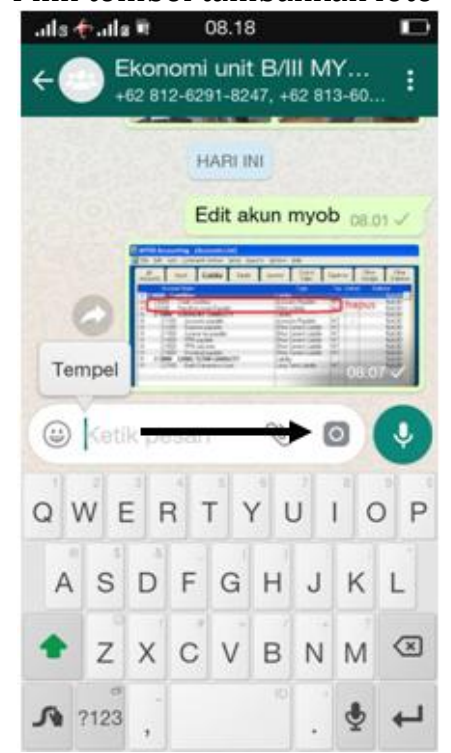

- Kemudian akan muncul pilihan untuk menambahkan foto, pilihan pertama bias dengan menambakan foto langsung dengan menggunakan kamera atau dengan menambahkan foto yang sudah ada di handphone. 


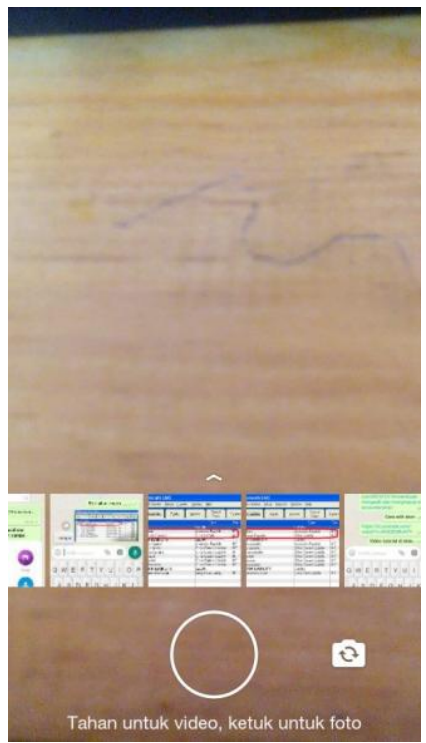

- Setelah memilih foto yang akan di tampilkan, berilah keterangan pada gambar dengan mengetuk tombol Tambahkan keterangan. Apabila sudah selesai pilihlah tombol kirim.

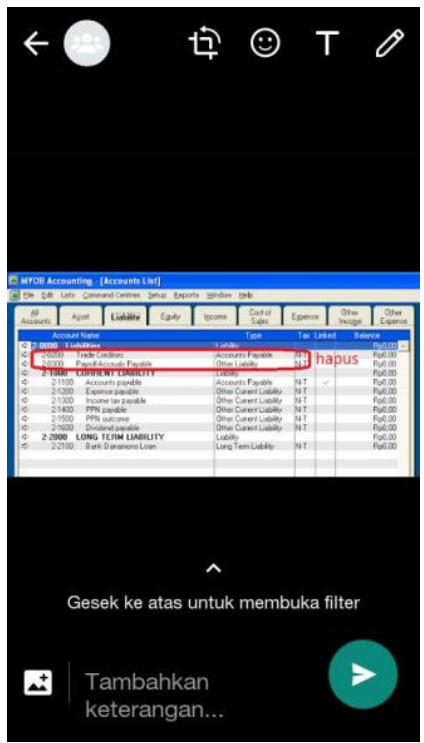


Pada materi pelajaran dapat juga ditambahkan link sebagai referensi tambahan atau referensi lanjut, caranya dengan mengcopy alamat url atau alamat web yang akan dibagikan kemudian dilanjutkan dengan mempaste di kolom materi. Keterangan tambahan yang mendukung materi pelajaran dapat juga berupa link video dari situs https://www.youtube.com/.

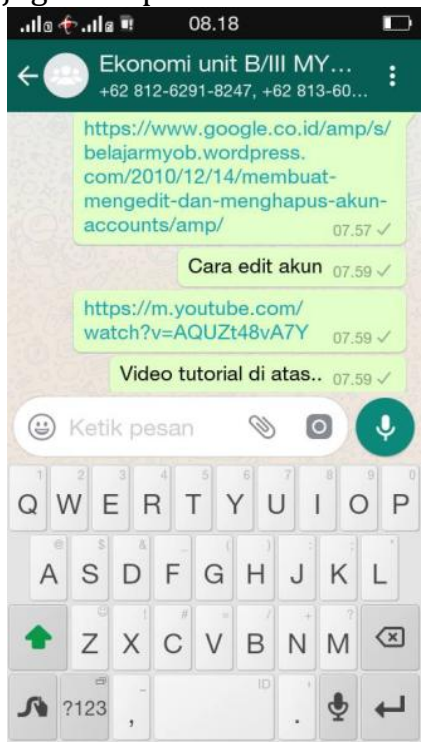

Siswa sebagai anggota grup dapat melakukan tanya-jawab ataupun memberikan masukan terhadap materi perkuliahan yang sedang dibahas. Grup whatsapp ini juga dapat digunakan sebagai wadah mengirimkan tugas berupa file pdf, word, dan myob. 


\section{BAB V}

\section{WEBSITE SEBAGAI MEDIA PEMBELAJARAN}

\section{Pengertian WeBsite}

Perkembangan zaman telah membawa perubahan yang sangat signifikan dalam kehidupan manusia, perubahan ini berjalan begitu cepat dan drastis. Salah satu bentuk perkembangan zaman yang paling cepat berkembang adalah internet, hamper segala sisi kehidupan manusia saat ini berhubungan dan menggunakan internet sebagai kebutuhan sehari-hari. Internet pada prakteknya selalu menggunakan website sebagai media akses. Website atau yang biasa di singkat web merupakan suatu kumpulan dari halaman yang saling berhubungan dan dapat diakses melalui halaman depan (home page) menggunakan sebuah browser. Website menampilkan informasi data teks, data gambar diam atau gerak, data animasi, suara, video dan atau gabungan dari semuanya, baik yang bersifat statis maupun dinamis yang membentuk satu rangkaian bangunan yang saling terkait dimana masing-masing dihubungkan dengan jaringan-jaringan halaman (hyperlink).

Website merupakan fasilitas internet yang menghubungkan dokumen dalam lingkup lokal maupun jarak jauh. Dokumen pada website disebut dengan web page dan link dalam website memungkinkan pengguna bisa berpindah dari satu page ke page lain (hyper text), baik diantara page yang disimpan dalam server yang sama maupun server diseluruh dunia. Pages diakses dan dibaca melalui browser seperti Netscape Navigator atau Internet Exploler berbagai aplikasi browser lainnya. ${ }^{17}$

Website merupakan kumpulan dari halaman-halaman yang berhubungan denganfile-file lain yang saling terkait. Dalam sebuah website terdapat satu halamanyang dikenal dengan sebutan homepage. Homepage adalah sebuah halaman yangpertama kali dilihat ketika seseorang mengunjungi sebuah website (Risky dkk.,2013). Website merupakan kumpulan halaman web yang saling terhubung dan file-filenya

${ }^{17}$ Hakim, Lukmanul dan Uus Musalini, Cara Cerdas Menguasai Layout, Desain dan. Aplikasi Web. (Jakarta, PT Elex Media Komputindo, 2004). 
saling terkait. Web terdiri dari page atau halaman, dan kumpulan halamanyang dinamakan homepage. Homepage berada pada posisi teratas dengan halamanterkait berada di bawahnya. Halaman di bawah homepage disebut child page yangberisi hyperlink ke halaman lain dalam web (Gregorius, 2001).

\section{JENIS-JENIS WEBSITE}

Banyaknya jumlah website yang dapat ditemukan saat berselancar di dunia maya (internet) memunculkan banyaknya jenis-jenis website dengan tema yang berbeda. Berikut ini beberapa jenis website yang sering digunakan.

Macam-macam website

1. Portal

Portal, seperti Yahoo!, adalah situs Web yang yang menawarkan beragam layanan internet dari satu lokasi tunggal yang mudah digunakan. Misalnya menawarkan mesin pencari, direktori, berita terbaru, e-mail, game, dan banyak lagi. Contoh portal lainnya: AltaVista, AOL, MSN, dan Netscape.

2. Berita

Situs macam ini mengandung materi terbaru yang berhasil diliput dan ditampilkan dalam Web. Keuangan, olahraga, selebritis, hingga berita politik. Hal-hal yang biasanya hanya kita dapatkan dari televisi, radio, amupun surat kabar sekarang dapat diakses dengan mudah dengan sekali klik. Misalnya situs berita CNN.

3. Informasi

Jaman sekarang orang haus akan informasi, dan di Web terlah terdapat banyak situs-situs berisi banyak informasi yang susah didapat di dunia nyata. Ingin tahu lebih banyak tentang chord gitar misalnya, silakan buka Ulimate-guitar.

4. Bisnis

Situs ini berisi promosi barang atau jasa yang ditawarkan lewat internet. Biasanya dimiliki oleh perusahaan yang benar-benar eksis di dunia nyata. Tidak menutup kemungkinan kita dapat memesan barang secara online. Situs yang popular diantarnya adalah:Ebay

5. Pendidikan

Siapa bilang belajar cuma di sekolah dan buku? Di Web ada banyak situs pembelajaran yang dapat diandalkan mengisi waktu luang. Bahkan ada beberapa universitas yang menawarkan kuliah secara online dan mendapat seftifikat lewat cyberworld. Guru-guru 
sekolah yang melek internet juga biasanya memasang bahan pembelajaran dalam situs mereka untuk dapat dimanfaatkan anak didiknya. Salah satu contoh situs pebelajaran tentang komputer adalah:IImu Komputer.

6. Hiburan

Situs ini menawarkan hal-hal yang menarik dan inovatif. Mereka menyediakan video, lagu, games, dan masih banyak lagi. Contoh situs tentang download video misalnya, adalah Youtube.

7. Advokasi

Kita dapat menemukan isi tentang tujuan, pendapat, atau gagasan untuk meyakinkan pembaca bahwa hal itu adalah benar. Biasanya situs seperti ini merupakan buah pikiran dari orang-orang dari golongan tertentu. Misalnya situs Richdad.

8. Blog

Kependekan dari Weblog. Semacam buku harian atau jurnal, yang dipergunakan pemiliknya untuk menulis hal-hal yang disukainya. Isi blog satu dengan yang lain bervariasi, tergantung pola pikir pemiliknya. Dapat dibuat sendiri atau dengan menggunakan layanan gratis di internet, misalnya Wordpress. Contoh blog ya, Aer Puteh ini.

9. Wiki

Ini adalah situs hasil kolaborasi antar pengguna, yang mengubah, menambah, atau menghapus isi dari situs Web tersebut. Data penyuntingan tersebut biasanya disimpan di halaman Web untuk ditentukan masalah ketepatannya. Situs ini berbeda denga blog karena pembaca blog tidak dapat menyinting isi dari siatu blog, kecuali pemiliknya sendiri.

Wikipedia adalah salah satu contoh wiki yang populer.

10. Agregator Isi

Situs ini dinamakan juga Content Agregator, adalah perusahaan yang mendistribusikan atau menampilkan berita terbaru dari Web dan menyebarkannya pada pengguna. Aktifitas ini biasa disebut feed dan menggunakan fasilitas RSS (Really Simple Syndication). Hal ini memungkinkan kita tidak tertinggal berita dan selalu up-to-date tentang konten suatu situs. Salah satu contohnya adalah blogindonesia yang menampilkan feed dari blog-blog yang terdaftar.

11. Perorangan

Semua orang dapat membuat situs pribadi dengan berbagai alasan. Apalagi sekarang orang bisa dengan mudah membuat situs dengan 
bantuan software tertentu seperti Dreamweaver. Isinya bergantung dengan kebutuhan pemilik, dan ia bebas mendesain situsnya dengan kreasinya sendiri. Misalnya situs It-he Software.

\section{PEMANFAATAN WEBSITE SEBAgAI MEDIA PEMBELAJARAN}

Banyaknya website yang menggunakan tema pendidikan sebagai isi dan pembahasannya dan banyaknya waktu digunakan oleh mahasiswa untuk mengakses internet, maka ada baiknya memanfaatkan website yang bertemakan pendidikan sebagai media pembelajaran. Pemanfaatan website sebagai media pembelajaran ini sangat mudah, cukup dengan memberikan alamat-alamat website yang memuat materi pelajaran kepada siswa, yang kemudian akan digunakan sebagai sumber materi pelajaran. Berikut ini beberapa website yang dapat digunakan sebagai media pembelajaran.

1. Zenius Education dengan alamat website https://www.zenius.net/ Zenius Education merupakan website pendidikan yang menyediakan berbagai materi pelajaran sekolah mulai dari tingkat SD, SMP, dan SMA bahkan SBMPTN. Website ini memiliki tujuan agar para pelajar di Indonesia mendapatkan pengalaman belajar yang hebat, seru dan menyenangkan sehingga mereka memiliki motivasi belajar mandiri yang didasari oleh rasa penasaran terhadap ilmu pengetahuan. Pembelajaran yang disediakan oleh zenius education menekankan kepada science and reason, karena dengan menerapkan prinsip berpikir saintifik dan rasional pada proses pertimbangan, analisis, dan pengambilan keputusan yang penting. Materi pelajaran yang dapat ditemukan di website zenius education juga tersedia dalam bentuk video, sehingga materi yang disampaikan lebih menarik dan mudah untuk dipahami. 


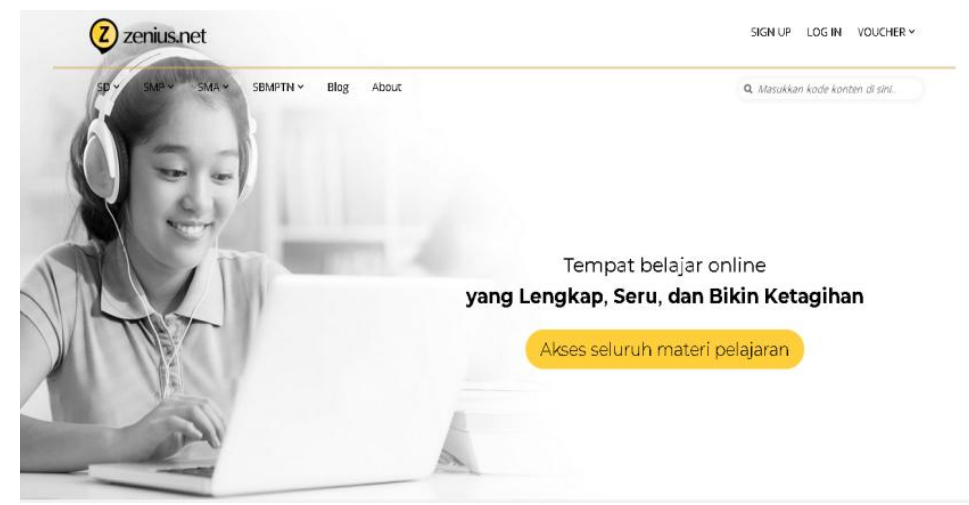

2. Kelaskita dengan alamat website https://kelaskita.com/.

Kelaskita adalah media online untuk memudahkan membuat dan mengikuti kelas belajar secara online bersama peserta didik, teman, tim atau komunitas. Kelaskita bertujuan untuk berkontribusi mencerdaskan Indonesia dengan membuat media belajar online yang mudah, murah, menyenangkan dan bisa diakses dari mana dan oleh siapa saja di seluruh dunia. KelasKita juga mencoba menjadi solusi bagi mereka yang ingin meningkatkan kemampuan diri tapi terhalang oleh jarak dan waktu untuk belajar secara rutin di sebuah institusi pendidikan.

Kelaskita menyedia bahan pelajaran yang dapat dapat diakses secara online, bahan pelajaran dapat berupa bahan bacaan dan berupa video pemebelajaran. Banyak sekali fitur yang dapat dimanfaatkan di website kelaskita, membuat kelas online, diskusi belajar online, dan dapat juga digunakan untuk membuat soal pelajaran berupa quiz. 


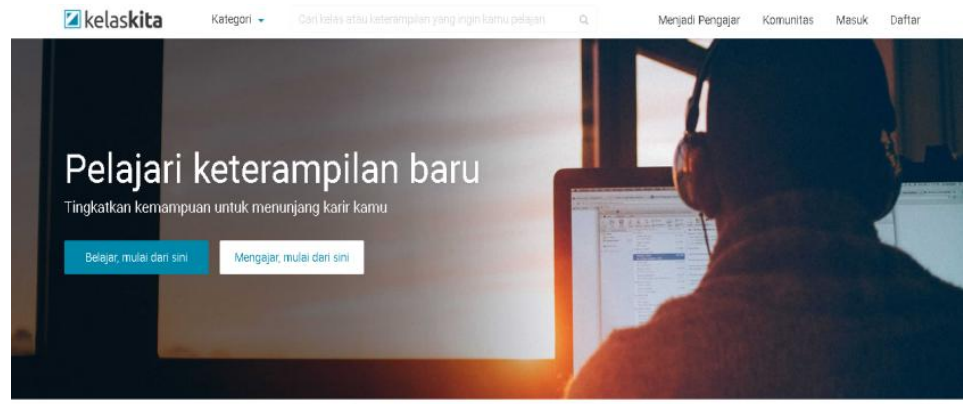

Belajar Pemrograman, Bahasa, dan Desain Grafis Online

Weith dar $500+$

3. IImu computer dengan alamat http://ilmukomputer.org/ IlmuKomputer.Com adalah komunitas eLearning yang membagi literatur dan materi kuliah secara bebas dan gratis di bidang computing alias ilmu komputer dan teknologi informasi dalam bahasa Indonesia. Misi utama kami adalah mengambil bagian dalam usaha mencerdaskan anak bangsa, terutama dalam pendidikan ilmu komputer (computing). Materi gratis dengan Lisensi Open Content tersedia dalam format PDF yang bebas untuk didownload. Tersedia juga versi offline dalam bentuk CD untuk yang kesulitan mangakses situs ini secara online.

IlmuKomputer.Com mengajak masyarakat Indonesia di manapun berada, untuk menbagi (share) pengetahuan melalui tulisan. Kami telah menyediakan Format Tulisan dengan prosedurnya untuk mempermudah anda dalam menulis dan mengupload artikel. Diskusi berbagai topik di bidang computing dapat dilakukan melalui beberapa Mailing List yang kami pisahkan berdasarkan kategori bahasan. Tersedia juga Konsultasi Online gratis melalui Yahoo Messenger untuk yang kesulitan mengikuti berbagai materi yang ada di situs ini. 


\section{IlmuKomputer.Com \\ ikatlah ilmu dengan menuliskannya}

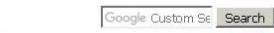

literaturs kompates Indoneria teslenglua os

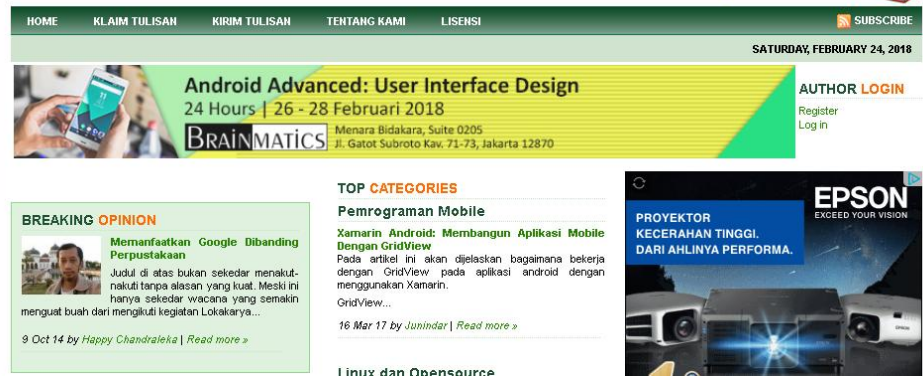

4. Muslim.or.id dengan alamat https://muslim.or.id/

Muslim.or.id adalah situs yang dikelola oleh mahasiswa dan alumni di Yogyakarta dan sekitarnya. Muslim.or.id berusaha menyebarkan dakwah Islamiyyah Ahlu Sunah wal Jama'ah di jagad maya. Moto Muslim.or.id adalah "Memurnikan Aqidah, Menebarkan Sunah".

Website ini mengambil moto "Memurnikan Aqidah" karena banyaknya kerancuan-kerancuan yang tersebar di kalangan masyarakat, tentang Aqidah Islamiyyah. Moto "Menebarkan Sunah" karena merajalelanya berbagai macam ibadah yang tidak bersumber dari ajaran Rasulullah shallallahu 'alaihi wa sallam.

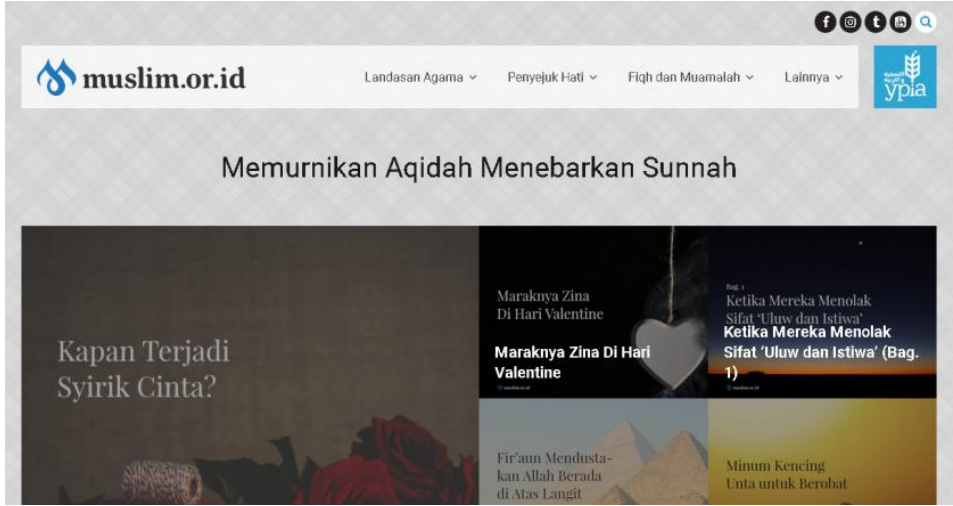

5. Youtube dengan alamat https://www.youtube.com/

Situs ini memungkinkan pengguna mengunggah, menonton, dan berbagi video, memakai teknologi Adobe Flash Video dan HTML5 untuk menampilkan berbagai macam konten video buatan 
pengguna, termasuk klip film, klip TV, dan video musik. Selain itu ada pula konten amatir seperti blog video, video orisinal pendek, dan video pendidikan. Kebanyakan konten di YouTube diunggah oleh individu, meskipun perusahaan-perusahaan media seperti CBS, BBC, Vevo, Hulu, dan organisasi lain sudah mengunggah material mereka ke situs ini sebagai bagian dari program kemitraan YouTube. Pengguna tak terdaftar dapat menonton video, sementara pengguna terdaftar dapat mengunggah video dalam jumlah tak terbatas.

Banyak sekali jenis video yang bias ditemukan di situs youtube, salah satunya tentang pendidikan, tutorial, dan video motivasi. Situs youtube ini dapat digunakan sebagai media pembelajaran karena juga terdapat video-video yang berisi tentang materi berbagai pelajaran. Penggunaan situs youtube tergolong mudah, cukup dengan mengetikkan kata pencarian di kolom search kemudian video yang dicari akan muncul.

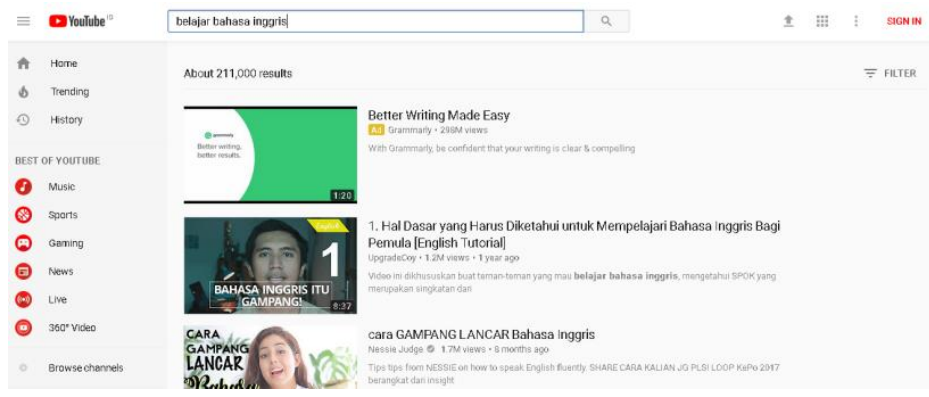

6. Wikipedia dengan alamat https://www.wikipedia.org/

Wikipedia adalah proyek ensiklopedia multibahasa dalam jaringan yang bebas dan terbuka, yang dijalankan oleh Wikimedia Foundation, sebuah organisasi nirlaba yang berbasis di Amerika Serikat. Nama Wikipedia berasal dari gabungan kata wiki dan encyclopedia. Setiap orang yang ingin menggunakan isi bebas Wikipedia, kapan pun, dapat mengunduh artikel yang mendekati versi terbaru di dalam pangkalan data untuk tujuan bebas, dengan syarat. 


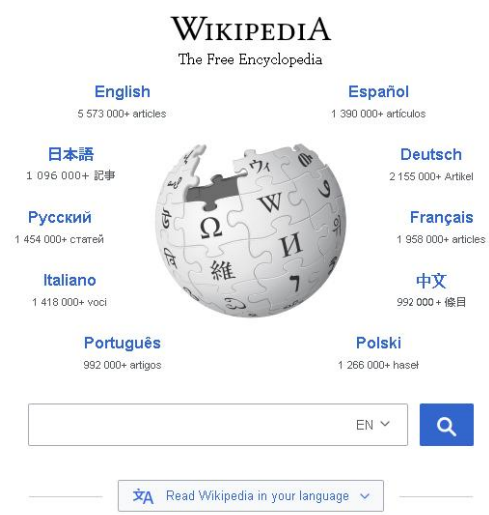

7. Kamus Bahasa Indonesia dengan alamat

https://www.kbbi.web.id/

Aplikasi Kamus Besar Bahasa Indonesia (KBBI) ini merupakan KBBI Daring (Dalam Jaringan / Online) yang dibuat untuk memudahkan pencarian, penggunaan dan pembacaan arti kata (lema/sub lema). Berbeda dengan beberapa situs web (website) sejenis, termasuk KBBI resmi dari PusatBahasa, kami berusaha memberikan berbagai fitur lebih, seperti kecepatan akses, tampilan dengan berbagai warna pembeda untuk jenis kata, tampilan yang pas untuk segala perambah web baik komputer desktop, laptop maupun telepon pintar dan sebagainya. Fitur-fitur selengkapnya bisa dibaca dibagian Fitur KBBI Daring. Database Utama KBBI Daring ini mengacu pada KBBI Daring Edisi III, sehingga isi (kata dan arti) tersebut merupakan Hak Cipta Badan Pengembangan dan Pembinaan Bahasa, Kemdikbud (dahulu Pusat Bahasa). Diluar data utama, kami berusaha menambah kata-kata baru yang akan diberi keterangan tambahan dibagian akhir arti atau definisi dengan "Definisi Eksternal". Semoga semakin menambah khazanah referensi pendidikan di Indonesia dan bisa memberikan manfaat yang luas. 


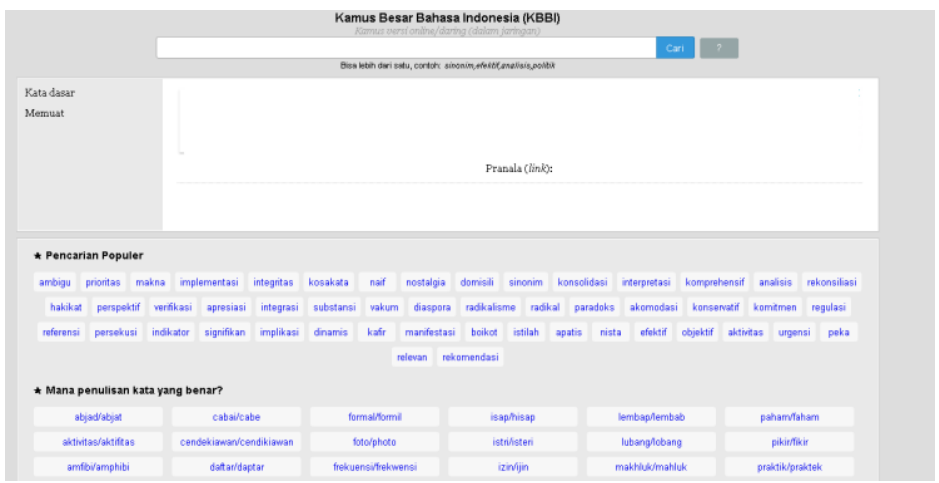




\section{$B A B$ VI}

\section{MEDIA PENYIMPANAN}

Guna mendukung media pembelajaran berbasis internet ini, maka diperlukan media penyimpanan yang memanfaatkan internet pula. Kemajuan teknologi yang begitu pesat telah mengubah kebiasaan manusia, salah satunya mengenai cara menyimpan data, dulu untuk menyimpan data selalu menggunakan bantuan flahsdisk, hardisk, atau media penyimpanan yang lebih lama lagi seperti disket. Saat ini dengan memanfaatkan koneksi internet, data-data dapat disimpan di cloud storage. Kini banyak orang yang memanfaatkan cloud storage sebagai media penyimpanan. Ada banyak manfaat yang bisa didapat saat data disimpan di cloud storage, seperti keamanan yang lebih terjamin, kapasitas yang lebih besar, lebih sederhana dan ringkas, hingga efisiensi waktu. Data bisa mengakses data di mana saja dan kapan saja, tanpa perlu repot membawa flashdisk maupun harddisk. Sedikit kelemahannya yaitu memerlukan koneksi internet yang stabil agar bisa menyimpan dan mengambil data di dalam cloud storage.

Saat ini banyak sekali penyedia layanan yang bisa digunakan secara gratis. Beberapa layanan cloud storage milik Google, yaitu Google Drive juga layanan lainnya seperti : one drive, drop box, dan mega. Penggunaan media penyimpanan ini tergolong mudah, dan layanannya juga disediakan gratis, sehingga tidak memerlukan biaya tambahan untuk menyimpan, maupun mengambil data yang telah di simpan.

Dengan kemudahan yang diberikan tersebut cloud storage juga memiliki beberapa kelebihan dan kekurangan diantaranya :

Kelebihan Cloud Storage :

1. File tidak mudah rusak, menyimpan data pada layanan cloud storage, bisa dipastikan data yang tersimpan tidak akan rusak. Kualitas serta keadaan file tersebut, akan tetap sama seperti waktu pertama kali kita mengunggahnya. Kelebihan layanan cloud ini memang tidak dimiliki 
oleh media penyimpanan fisik, dimana file bisa saja terhapus atau terinveksi virus.

2. Media Penyimpanan Tidak Mudah Rusak, media penyimpanan tidak mudah rusak karena tidak berupa benda fisik. Penyedia pelayanan akan menjaga server dengan baik, untuk meminimalisir terjadinya kerusakan perangkat. Ketika terjadi kerusakan pada perangkat, maka mereka sudah secara otomatis menyiapkan back-up data yang disimpan di dalam server tersebut.

3. Tidak memenuhi media penyimpanan fisik yang dimiliki, ketika menggunakan cloud storage tentunya akan jauh lebih menghemat tempat media penyimpanan tambahan lain seperti hard disk atau flash disk karena data akan tersimpan pada database dalam bentuk digital sehingga tidak akan memenuhi memori penyimpanan di dalam $\mathrm{pc}$ maupun hp.

4. Bisa diakses dimana saja, dengan menggunakan cloud storage kita tidak perlu membawa hard disk maupun flash disk lagi kemanapun karena semua data yang akan kita gunakan sudah tersimpan di server. Ketika kita membutuhkannya tinggal membuka dan mengunduhnya saja kapanpun dan dimanapun yang terhubung dengan jaringan internet.

5. Keamanan Privasi, Privasi kita juga lebih terjaga karena hanya kita sendiri yang dapat mengakses maupun mengelolahnya, beda dengan media penyimpanan seperti flashdisk yang bisa di pinjam orang lain dan otomatis pengguna lain dapat melihat isi file kita. Sedangkan Cloud Storage untuk mengakses di perlukan login ke akun terlebih dahulu menggunakan Username dan Password.

\section{Kekurangan Cloud Storage :}

1. Membutuhkan Akses Internet, ketika akan mengakses data-data yang akan digunakan kita harus terhubung dengan jaringan internet untuk dapat mengakses cloud storage, jika tidak maka aplikasi ini tidak dapat diakses. Untuk dapat mengunggah maupun menyimpan file dengan cepat juga sangat dibutukan koneksi internet yang stabil.

2. Untuk file berukuran besar, dibutuhkan kecepatan internet yang tinggi. Apabila akan menyimpan data yang memiliki ukuran yang besar tentu akan menjadi masalah jika internet tidak dalam kondisi stabil. Koneksi internet harus dalam kondisi stabil dan cepat unmtuk dapat mengakses file secara cepat, jika tidak maka akan sangat membutuhkan waktu yang cukup lama. 
3. Sulit diakses ketika server sedang mengalami traffic yang tinggi atau down. Ketika server mengalami down, maka data yang telah disimpan dalam cloud server pun akan menjad sulit untuk diakses. Dan biasanya, proses perbaikan atau pemulihan dari cloud server yang mengalami down ini membutuhkan waktu yang cukup lama, dan tidak dapat ditentukan secara pasti.

4. Rentan terhadap peretasan, Cloud storage juga memiliki kelemahan yaitu rentan terhadap peretasan dan pembobolan terhadap layanan tersebut. File-file ataupun data yang telah kita simpan di dalam cloud storage bisa saja dibajak oleh orang yang tidak bertanggung jawab.

\section{GOOGLE DRIVE}

Untuk menggunakan google drive, terlebih dahulu membuat akun Google. Berikut ini merupakan beberapa langkah yang perlu dilakukan. Untuk membuat akun di Google, perlu mengakses gmail.com terlebih dahulu. Setelah masuk ke Gmail, kamu bisa memilih pilihan 'Create account'.

\section{Google \\ Create your Google Account}

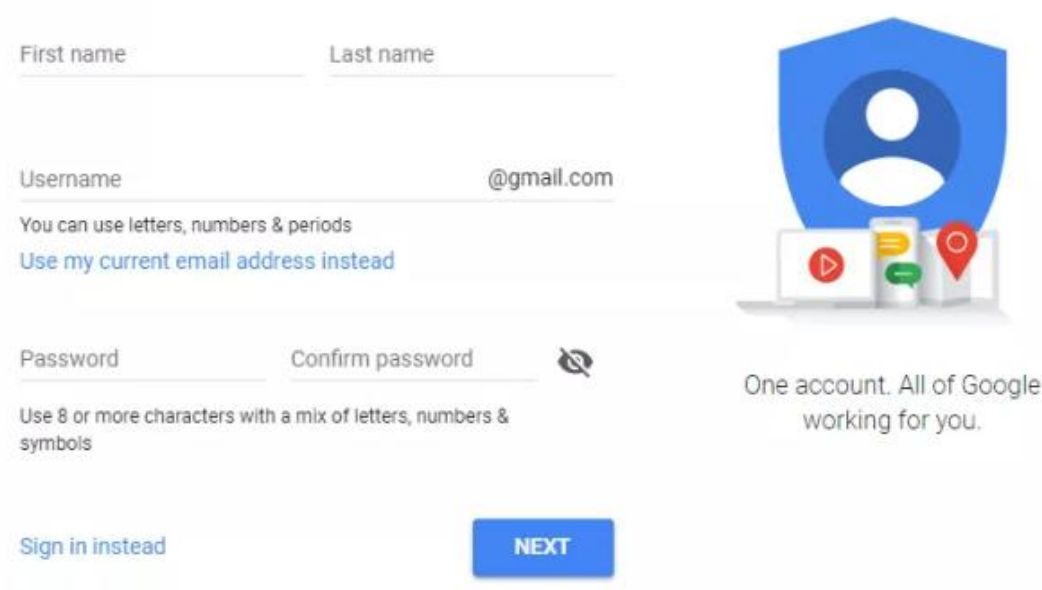

Setelah itu muncul kolom yang harus diisi dengan lengkap. Setelah diisi dengan lengkap, kamu harus menekan tombol 'Next Step'. Nantinya akan 
muncul halaman verifikasi melalui sms atau panggilan telepon. Setelah memasukkan kode verifikasi tersebut, akun Gmail telah siap digunakan.

Untuk menambahkan data yang akan disimpan di google drive, caranya dengan menekan tombol NEW,

\begin{tabular}{|c|c|c|}
\hline & Drive & Q Search Drive \\
\hline & New & My Drive - \\
\hline - $\Delta$ & My Drive & Name $\uparrow$ \\
\hline 옹. & Shared with me & ganjil 2016 \\
\hline () & Recent & ganiil 20161 \\
\hline$\vec{W}$ & Starred & ganjil 20161 \\
\hline 而 & Trash & ganjil 2017 \\
\hline
\end{tabular}

Setelah memilih tombol new, maka pilih File upload, selanjutnya pilihlah file/data yang akan di upload ke google drive

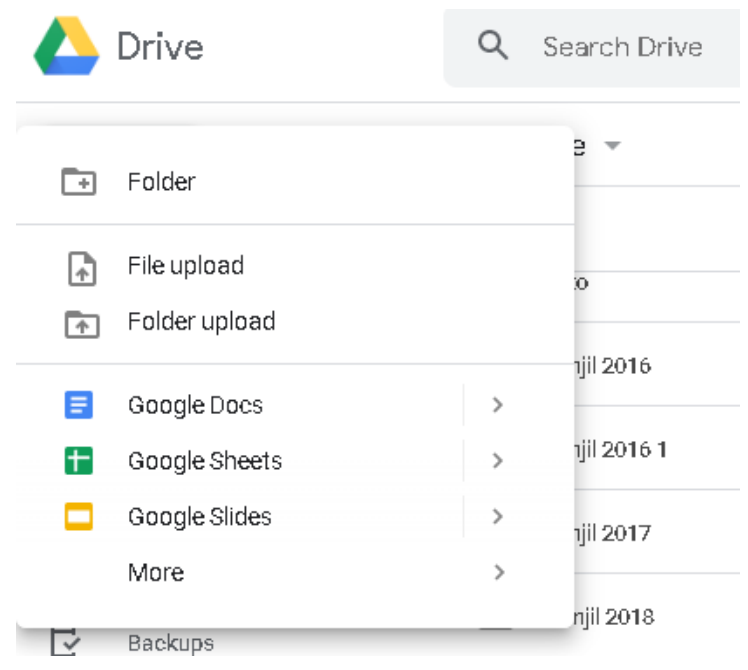


Untuk melihat data/file yang telah kita simpan di google drive, caranya dengan masuk kea kun google drive dan kita akan bisa melihat dan mengunduh data tersebut.

Untuk membagikan link file atau data, caranya dengan memilih file yang akan di bagikan, klik kanan dan pilih Get Shareable Link, maka otomatis link file akan tercopy dan tinggal paste di mana akan dibagikan.

\begin{tabular}{|c|c|c|}
\hline$\leftrightarrow$ & Open with & $>$ \\
\hline$\stackrel{\circ}{\circ}$ & Share & \\
\hline લ) & Get shareable link & \\
\hline$\rightarrow$ & Move to & \\
\hline $\boldsymbol{s}$ & Add to Starred & \\
\hline 0 & Rename & \\
\hline P & Change color & $>$ \\
\hline Q & Search within FILE BERSAMA & \\
\hline (i) & View details & \\
\hline$\downarrow$ & Download & \\
\hline
\end{tabular}

\section{ONE DRIVE}

Media penyimpanan One Drive disediakan oleh Microsoft, penyimpanan di one drive menyediakan space yang cukup besar, yaitu sebesar $15 \mathrm{~Gb}$. Pertama-tama silahkan masuk ke situs https://onedrive.live.com/about/enus/ dan lanjutkan dengan login ke akun akun Microsoft. Apabila belum memiliki akun, maka silahkan daftar terlebih dahulu. 


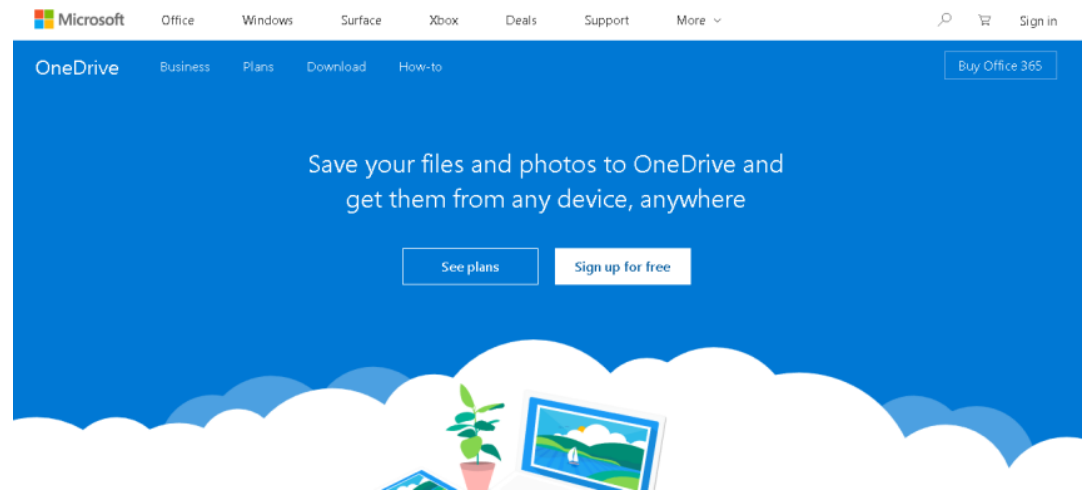

Untuk mengunggah file ke one drive, sama hal nya dengan penggunaan google, drive, file hanya perlu di upload saja dengan memilih tombol upload.

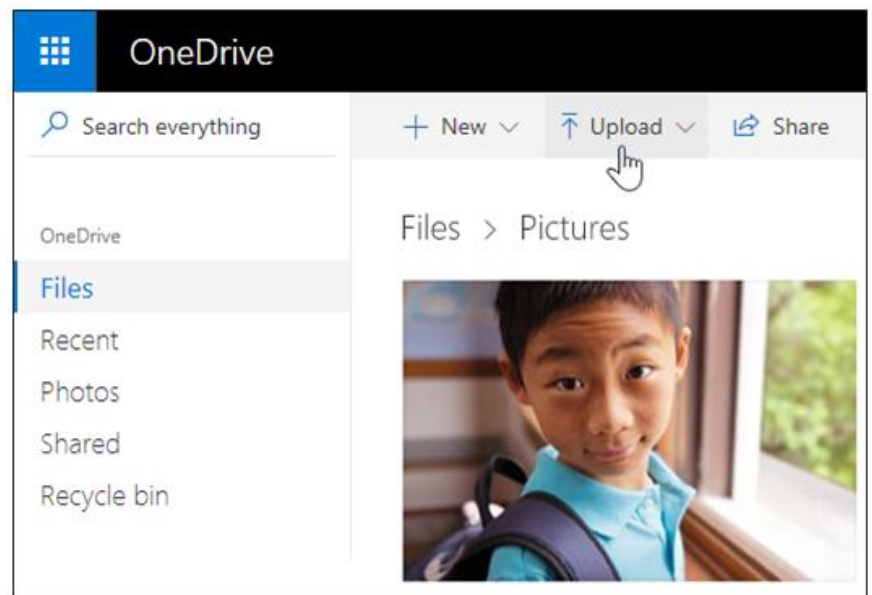

\section{DROPBOX}

Dropbox adalah layanan hosting file yang dioperasikan oleh perusahaan Amerika Dropbox, Inc., yang berkantor pusat di San Francisco, California. Layanan ini menawarkan penyimpanan cloud, sinkronisasi file, cloud pribadi, dan klien software. Media penyimpanan dropbox ini biasanya digunakan untuk menggunakan file surat saja, walaupun dalam prakteknya banyak data yang dapat disimpan. Untuk dpat menggunakan layanan 
dropbox, terlebih dahulu akses alamat https://www.dropbox.com/ dan lakukan proses sign in, untuk menggunakan layanan ini dapat juga dengan memanfaatkan akun google yang telah dimiliki.

$$
\text { Sign in Download }
$$

\begin{tabular}{|l|} 
Sign up \\
or sign in to your account \\
\hline First name \\
\hline Last name \\
\hline Email \\
\hline Password \\
\hline
\end{tabular}

Untuk login dengan menggunakan akun google, tinggal pilih tombol sign up with google.

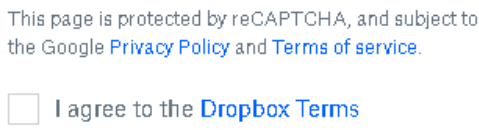

Sign up

Sign up with Google

Halaman awal dropbox, dapat dilihat seperti gambar berikut ini:

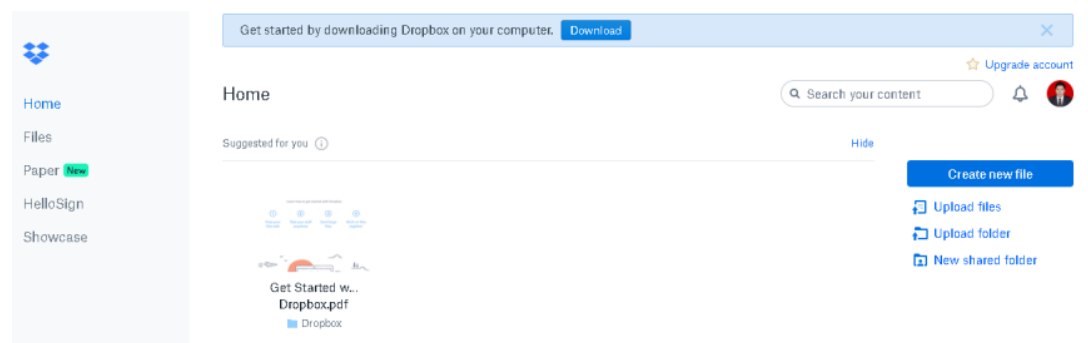


Untuk menggunakannya juga mudah, sama seperti penggunaan media penyimpanan lainnya, untuk menyimpan data pilihlah tombol Upload File yang terdapat di bagian sisi kanan, atau bias juga menyimpan fila file dalam bentuk folder, dengan memilih tombol upload folder.

\section{MEGA}

Mega merupakan salah satu situs file hosting yang cukup banyak digunakan. Situs ini menyedia media penyimpanan yang cukup besar, bahkan melebihi ruang yang disediakan oleh google drive, onedrive, dan dropbox. Ruang yang disediakan secara gratis bahkan 3 kali lipat yang disediakan oleh google drive, yaitu sebesar 50GB.

Untuk dapat menggunakan layanan Mega, terlebih dahulu akses situs berikut ini: https://mega.nz/, kemudian buatlah akun mega dengan mengunakan tombol Create Account.

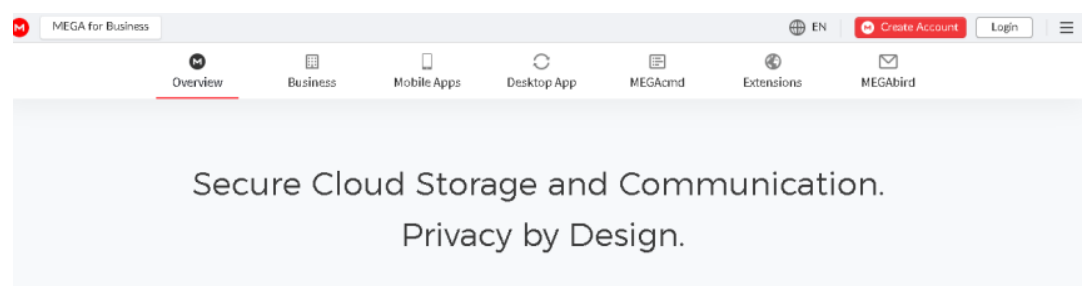

Create Account

Proses pembuatan akun ini hamper sama dengan proses pembuatan akun penyimpanan lainnya, yaitu dengan mengisi beberapa isian berikut ini:

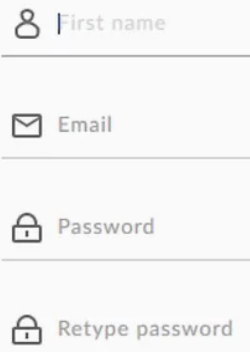


- "First Name" dan "Last Name" - Masukkan nama depan dan nama belakang.

- "E-Mail" - Masukkan alamat surel yang aktif dan masih bisa diakses.

- "Password" - Ketikkan kata sandi akun yang kuat.

- "Retype Password" - Ketikkan kembali kata sandi untuk memastikan dua kata sandi yang Anda tikkan sama atau sesuai.

Apabila semua proses membuat akun sudah selesai, maka akan masuk ke halaman mega.nz seperti berikut ini, seperti biasa untuk membuat folder baru pilih new folder, untuk mengunggah fil pilih uple file, dan untuk mengunggah folder pilih folder upload.

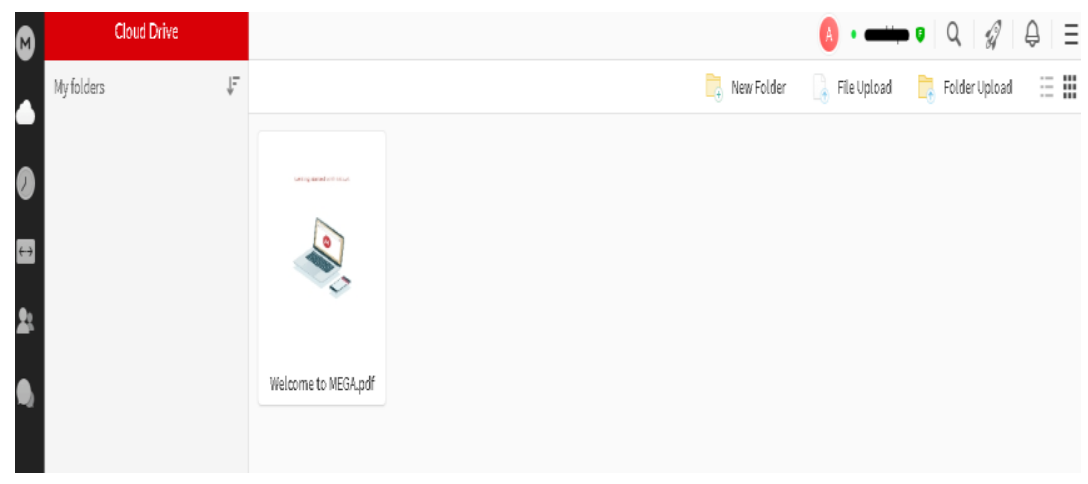




\section{DAFTAR PUSTAKA}

Agung Herutomo. 2010. Conquering Web 2.0. Jakarta: PT Elex media Komputindo.

Anggara, Agung Melisa. 2013. Pemanfaatan Jejaring Sosial Melalui Grup Dalam Facebook Sebagai Sarana Pengelolaan Pembelajaran Pada Mata Pelajaran Teknologi Informasi Dan Komunikasi Kelas X Sma (Siswa Kelas X6 Dan X7 Sman 1 Banjarharjo - Brebes). Semarang: Universitas Negeri Semarang.

Asnawir dan M. Basyiruddin Usman. 2002. Media Pembelajaran. Jakarta: Ciputat Pers.

Awal Kurnia Putra Nasution. 2017. Penggunaan Grup Facebook Sebagai Virtual Class. Aceh: Jurnal Assalam.

Azhar Arsyad. 2005. Media Pembelajaran. Jakarta: PT. Raja Grafindo Persada.

Djamarah, Syaiful Bahri dan Aswan Zain. 2006. Strategi belajar Mengajar. Jakarta : PT. Rineka Cipta.

Gagne, Robert M, Briggs Leslie J, and Wager Walter W. 1992. Principles of Instructional Design. USA : Holt, Rinehart and Winston

Gween Solomon, lynne Scrum. 2011. Web 2.0 Panduan bagi para pendidik. Jakarta : PT indekx.

Hakim, Lukmanul dan Uus Musalini. 2004. Cara Cerdas Menguasai Layout, Desain, dan Aplikasi Web. Jakarta: PT Elex Media Komputindo.

Hengky Alexander Mangkulo dan Winpec Solution. 2010. Facebook For Sekolahan. PT Elex Media Komputindo: Jakarta.

http://tekno.liputan6.com/read/2926217/indonesia-negara-ke-4-denganpengguna-facebook-teraktif-di-dunia

http://www.muhanik.com/2017/09/Sejarah-perkembangan-bloglengkap.html

http://www.pengertianahli.com/2014/07/pengertian-media-dan-jenismedia.html

https://id.wikipedia.org/wiki/Internet

https://www.whatsapp.com/about/

Levie, W. H. and Lentz, R.. 1982. Effects of text illustrations: a review of research. Educational Communication and Technology. Journal.

Oya Suryana dan Matamaya Studio. 2008. Membanggun Blog Wordpress. Jakarta: PT elex Media Komputindo. 